\title{
A systematic review and meta-analysis of stereotactic body radiation therapy versus surgery for patients with non-small cell lung cancer
}

\author{
Christopher Cao, MD, PhD, ${ }^{\mathrm{a}, \mathrm{b}}$ Daniel Wang, MD, ${ }^{\mathrm{c}}$ Caroline Chung, MD, ${ }^{\mathrm{c}}$ David Tian, MD, \\ Andreas Rimner, MD, ${ }^{\mathrm{d}}$ James Huang, $\mathrm{MD},{ }^{\mathrm{a}}$ and David R. Jones, $\mathrm{MD}^{\mathrm{a}}$
}

\section{ABSTRACT}

Objective: Stereotactic body radiation therapy is the preferred treatment modality for patients with inoperable early-stage non-small cell lung cancer. However, comparative outcomes between stereotactic body radiation therapy and surgery for high-risk patients remain controversial. The primary aim of the present meta-analysis was to assess overall survival in matched and unmatched patient cohorts undergoing stereotactic body radiation therapy or surgery. Secondary end points included cancer-specific survival, disease-free survival, disease recurrence, and perioperative outcomes.

Methods: A systematic review of relevant studies was performed through online databases using predefined criteria. The most updated studies were selected for meta-analysis according to unmatched and matched patient cohorts.

Results: Thirty-two studies were identified in the systematic review, and 23 were selected for quantitative analysis. Surgery was associated with superior overall survival in both unmatched (odds ratio, 2.49; 95\% confidence interval, 2.10-2.94; $P<.00001$ ) and matched (odds ratio, $1.71 ; 95 \%$ confidence interval, $1.52-1.93 ; P<.00001)$ cohorts. Subgroup analysis demonstrated superior overall survival for lobectomy and sublobar resection compared with stereotactic body radiation therapy. In unmatched and matched cohorts, cancer-specific survival, disease-free survival, and freedom from locoregional recurrence were superior after surgery. However, stereotactic body radiation therapy was associated with fewer perioperative deaths.

Conclusions: The current evidence suggests surgery is superior to stereotactic body radiation therapy in terms of mid- and long-term clinical outcomes; stereotactic body radiation therapy is associated with lower perioperative mortality. However, the improved outcomes after surgery may be due at least in part to an imbalance of baseline characteristics. Future studies should aim to provide histopathologic confirmation of malignancy and compare stereotactic body radiation therapy with minimally invasive anatomical resections. (J Thorac Cardiovasc Surg 2019;157:362-73)

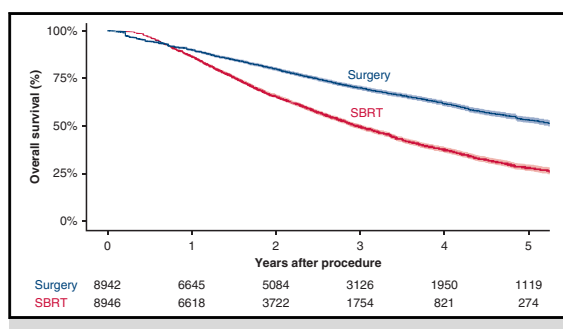

Kaplan-Meier graph of overall survival using data from matched patients with NSCLC.

\section{Central Message}

In matched patients with early-stage NSCLC, surgery was superior to SBRT in overall survival, cancer-specific survival, disease-free survival, and freedom from disease recurrence.

\section{Perspective}

With a paucity of randomized data, observational studies have used propensity score matching to minimize the risk of selection bias to compare surgery versus SBRT in patients with NSCLC. This systematic review and meta-analysis identified superior mid- and long-term clinical outcomes for surgery in both matched and unmatched patient cohorts. However, periprocedural mortality was lower for SBRT.

See Editorial Commentary page 374.
From the aThoracic Surgery Service and d Department of Radiation Oncology, Memorial Sloan Kettering Cancer Center, New York, NY; ${ }^{\mathrm{b}}$ Collaborative Research Group, Macquarie University, Sydney, Australia; and ${ }^{\mathrm{c}}$ Department of Medicine, Cornell University, New York, NY.

This work was supported, in part, by National Institutes of Health Cancer Center Support Grant P30 CA008748.

Received for publication May 16, 2018; revisions received Aug 17, 2018; accepted for publication Aug 30, 2018; available ahead of print Oct 25, 2018.

Address for reprints: David R. Jones, MD, Thoracic Surgery Service, Memorial Sloan Kettering Cancer Center, 1275 York Ave, Box 7, New York, NY 10065 (E-mail: jonesd2@mskcc.org).

$0022-5223 / \$ 36.00$

Copyright (c) 2018 by The American Association for Thoracic Surgery https://doi.org/10.1016/j.jtcvs.2018.08.075
Stereotactic body radiation therapy (SBRT) is the preferred treatment modality for patients with medically inoperable early-stage non-small cell lung cancer (NSCLC). ${ }^{1,2}$ Compared with conventional radiotherapy, SBRT delivers

Scanning this QR code will take you to the article title page to access supplementary information. 


$$
\begin{aligned}
& \text { Abbreviations and Acronyms } \\
& \begin{aligned}
\text { CI } & =\text { confidence interval } \\
\text { NSCLC } & =\text { non-small cell lung cancer } \\
\text { OR } & =\text { odds ratio } \\
\text { SBRT } & =\text { stereotactic body radiation therapy } \\
\text { VATS } & =\text { video-assisted thoracoscopic surgery }
\end{aligned}
\end{aligned}
$$

fewer fractions of high-dose radiation per fraction with increased precision, sparing the surrounding normal tissue to maximize the biologically effective dose while minimizing toxicity, resulting in improved local control and overall survival. ${ }^{3,4}$ The accumulating clinical experience with SBRT in prospective trials has led to heightened interest among the oncology community about the comparative outcomes of SBRT versus surgical resection for early-stage NSCLC in operable patients. ${ }^{5,6}$

Recently, a retrospective pooled analysis of 2 prematurely terminated randomized controlled trials suggested that SBRT is better tolerated than surgery and may lead to improved overall survival. ${ }^{7}$ However, several study limitations necessitate caution to avoid overinterpreting these results, and there remains a paucity of robust clinical data to support the above statement, given the heterogeneity of study cohorts. ${ }^{8,9}$ To address this issue, a number of studies have used propensity score matching to minimize the risk of selection bias. ${ }^{10}$ The purpose of the present systematic review and metaanalysis is to assess the clinical outcomes of SBRT versus surgery for patients with early-stage NSCLC. Primary end points included overall survival in matched and unmatched cohorts. Secondary end points included cancer-specific survival, disease-free survival, freedom from locoregional recurrence, freedom from distant recurrence, and perioperative mortality and morbidity. Each end point was assessed using matched and unmatched cohorts to compare relative outcomes, whenever possible. Subgroup analyses of lobectomy and sublobar resection versus SBRT were also performed for overall survival.

\section{MATERIALS AND METHODS \\ Literature Search Strategy}

A systematic review was performed using EMBASE and Ovid Medline, from their dates of inception to January 2018. To identify all potentially relevant studies, we combined the search terms ("SBRT" or "SABR" or "stereotactic" or "radiosurgery") and ("NSCLC" or "non-small cell lung" or "carcinoma, non-small cell lung") and ("surg*" or "resect*" or lobectomy) as either Medical Subject Headings or keywords. All identified articles were then assessed by applying the predefined selection criteria. A summary of search strategies and techniques has been described in detail previously. ${ }^{11}$

\section{Selection Criteria and Data Appraisal}

Eligible studies for selection in the systematic review were those in which comparative overall survival was reported for patients who underwent SBRT or surgical resection for NSCLC. When institutions published duplicate studies with accumulating numbers of patients or increased lengths of follow-up, only the most complete or updated reports were included for meta-analysis. Abstracts, case reports, conference presentations, editorials, expert opinions, and publications not written in English were excluded. Data were extracted from article texts, tables, figures, and supplementary material. Two investigators (D.W. and C.D.C.) independently reviewed each retrieved article. Discrepancies between the 2 reviewers were resolved by discussion and consensus. To assess the quality of the nonrandomized studies, the Newcastle-Ottawa scale was used to evaluate the selection, comparability, and outcomes reported in each study, with 0 to 3 stars indicating poor quality, 4 to 6 stars indicating moderate quality, and 7 or more stars indicating high quality. ${ }^{12}$

\section{Statistical Analysis}

When more than 4 studies provided relevant data on the same predetermined end point, meta-analysis was performed by combining the reported clinical outcomes of individual studies using a random effect model. Odds ratio (OR) and standard error were extracted or calculated from each study using methods described by Tierney and colleagues ${ }^{13}$ and Parma and colleagues. ${ }^{14}$ When calculations were not possible because of inadequate data, ORs were estimated using Kaplan-Meier graphs. $\mathrm{I}^{2}$ statistic was used to estimate the percentage of total variation across studies attributable to heterogeneity rather than chance. Meta-analysis was performed using Review Manager (version 5.1.2, Cochrane Collaboration, Oxford, UK). All $P$ values were 2 sided.

Individual patient survival data were reconstructed using Guyot's iterative algorithm to solve the Kaplan-Meier equations originally used to produce the published graphs. ${ }^{15}$ This algorithm used digitalized Kaplan-Meier curve data to find numeric solutions to the inverted Kaplan-Meier equations, and it assumes a constant, noninformative censoring mechanism. The reconstructed patient survival data were then aggregated to form the combined survival curve. Reconstructed Kaplan-Meier analyses were conducted using R (version 3.2.5, R Core Team, Vienna, Austria).

\section{RESULTS}

\section{Quantity and Quality of Trials}

Applying the predefined inclusion criteria, we identified a total of 2211 records through the electronic search. After identification of additional records through other sources and removal of duplicate studies, 1744 articles remained for screening. Of these, 1698 were excluded on the basis of title and abstract content. After review of the full text of the remaining 46 articles, 32 were found to meet the selection criteria for the systematic review. ${ }^{7,16-46}$ These included 1 retrospective pooled analysis of 2 randomized controlled trials and 31 observational studies, of which 24 provided data on propensity-matched populations. By selecting the most complete and updated studies from each institution or database, we identified 23 studies for quantitative meta-analysis. Quality assessment using the Newcastle-Ottawa Scale reported scores that ranged from 5 to 8 points, with a median of 6 points, indicating moderate quality overall. A summary of the study selection process is presented in the PRISMA chart in Figure E1, and a summary of each study, with detailed characteristics, is presented in Table 1. 
TABLE 1. Summary of studies comparing overall survival outcomes between stereotactic body radiation therapy and surgical resection for patients with non-small cell lung cancer

\begin{tabular}{|c|c|c|c|c|c|c|c|c|c|c|}
\hline \multirow[b]{2}{*}{ Institution } & \multirow[b]{2}{*}{ Author } & \multirow[b]{2}{*}{ Study period } & \multicolumn{2}{|c|}{$N$} & \multirow[b]{2}{*}{ Mortality } & \multirow[b]{2}{*}{ Morbidity } & \multirow[b]{2}{*}{ OS } & \multirow[b]{2}{*}{ DFS } & \multirow[b]{2}{*}{ CSS } & \multirow[b]{2}{*}{ REC } \\
\hline & & & $\overline{\text { SBRT }}$ & Surgery & & & & & & \\
\hline \multicolumn{11}{|l|}{ USA } \\
\hline \multirow[t]{16}{*}{ SEER } & Paul $^{16}$ & 2007-2012 & 714 & 2253 & & & • & & • & \\
\hline & Paul $^{16 *}$ & 2007-2012* & $643^{*}$ & $643^{*}$ & $*$ & * & * & $*$ & * & $*$ \\
\hline & Smith $^{17}$ & $2003-2010$ & 382 & $1496^{\mathrm{S}}$ & & & 0 & & & \\
\hline & & & & $7215^{\mathrm{L}}$ & & & & & & \\
\hline & Smith $^{17} *$ & 2003-2010* & $300 *$ & $300^{\mathrm{S} *}$ & $*$ & $*$ & * & $*$ & $*$ & $*$ \\
\hline & & & $243 *$ & $243^{\mathrm{L}^{*}}$ & & & & & & \\
\hline & Ezer $^{18}$ & 2002-2009 & 362 & 1881 & & ○ & 0 & & 0 & \\
\hline & Ezer $^{18 *}$ & $2002-2009^{*}$ & NS* & NS* & $*$ & $*$ & $O^{*}$ & $*$ & $\bigcirc *$ & $*$ \\
\hline & $\mathrm{Yu}^{19}$ & $2007-2009$ & 383 & 3852 & & & & & & \\
\hline & $\mathrm{Yu}^{19 *}$ & $2007-2009^{*}$ & $367 *$ & $711^{*}$ & ○* & * & $\bigcirc *$ & $*$ & $\bigcirc *$ & $*$ \\
\hline & Shirvani $^{20}$ & 2003-2009 & 382 & 8711 & $\bigcirc$ & & 0 & & $\bullet$ & \\
\hline & Shirvani $^{20} *$ & 2003-2009* & $251^{*}$ & $251^{\mathrm{L}^{*}}$ & $*$ & $*$ & * & $*$ & $*$ & $*$ \\
\hline & Shirvani $^{21}$ & $2001-2007$ & 124 & $6531^{\mathrm{L}}$ & & & 0 & & 0 & \\
\hline & & & & $1277^{\mathrm{S}}$ & & & & & & \\
\hline & Shirvani $^{21} *$ & 2001-2007* & $99 *$ & $99^{\mathrm{L} *}$ & $*$ & $*$ & $\bigcirc *$ & $*$ & $\bigcirc *$ & $*$ \\
\hline & & & $112 *$ & $112^{\mathrm{S} *}$ & & & & & & \\
\hline \multirow[t]{6}{*}{ NCBD } & Yerokun 22 & $2008-2011$ & 1778 & 4517 & & & 0 & & & \\
\hline & Yerokun $22 *$ & $2008-2011^{*}$ & $1584 *$ & $1584 *$ & $*$ & $*$ & $\bigcirc *$ & * & $*$ & $*$ \\
\hline & $\operatorname{Rosen}^{23}$ & 2008-2012 & 1781 & 13652 & 0 & & 0 & & & \\
\hline & $\operatorname{Rosen}^{23} *$ & 2008-2012* & $1781^{*}$ & $1781^{*}$ & * & $*$ & * & $*$ & $*$ & $*$ \\
\hline & Puri $^{24}$ & $1998-2010$ & 5887 & 111731 & 0 & & 0 & & & \\
\hline & Puri $^{24 *}$ & $1998-2010^{*}$ & $5355^{*}$ & $5355^{*}$ & * & $*$ & * $*$ & * & $*$ & $*$ \\
\hline \multirow[t]{2}{*}{ VA Cancer Registry } & Boyer $^{25}$ & 2001-2010 & 3012 & 8248 & - & - & 0 & & 0 & \\
\hline & Boyer $^{25 *}$ & $2001-2010 *$ & $468^{*}$ & $468^{*}$ & $*$ & $*$ & * & * & * & $*$ \\
\hline $\begin{array}{l}\text { VA Informatics and Computing } \\
\text { Infrastructure }\end{array}$ & Bryant $^{26}$ & 2006-2015 & 449 & 4069 & ○ & & ○ & & • & \\
\hline \multirow[t]{6}{*}{ Washington University } & Crabtree $^{27}$ & 2004-2010 & 151 & 458 & 0 & & 0 & $\bigcirc$ & & 0 \\
\hline & Crabtree $^{27 *}$ & 2004-2010* & $56^{*}$ & $56^{*}$ & $*$ & $*$ & $\bigcirc *$ & ?* & $*$ & ○* \\
\hline & Robinson $^{28}$ & 2004-2008 & 118 & 260 & $\bullet$ & $\bullet$ & $\bullet$ & & $\bullet$ & $\bullet$ \\
\hline & Robinson $^{28 *}$ & 2004-2008* & $76^{*}$ & $76^{*}$ & $*$ & * & ? $*$ & * & * & * \\
\hline & Puri $^{29}$ & $2000-2007$ & 76 & 462 & & & & & & \\
\hline & Puri $^{29 *}$ & $2000-2007 *$ & $57 *$ & $57^{*}$ & ○* & ○* & ○* & $*$ & $\bigcirc *$ & * \\
\hline \multirow[t]{4}{*}{ Weill Cornell Medical College } & Parashar $^{30}$ & 1993-2012 & 97 & $123^{\mathrm{W}}$ & & ○ & 0 & 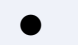 & & 0 \\
\hline & Port $^{31}$ & 2001-2012 & NR & NR & & & & & & \\
\hline & $\operatorname{Port}^{31} *$ & 2001-2012* & $23^{*}$ & $38^{\mathrm{W} *}$ & * & * & $\bigcirc *$ & $\bigcirc^{*}$ & $*$ & ○* \\
\hline & Parashar $^{32}$ & $1999-2010$ & 30 & 17 & & O & 0 & & & ○ \\
\hline \multirow[t]{2}{*}{ Michael DeBakey VAMC } & Cornwell $^{33}$ & 2009-2014 & 56 & 127 & & & & & & \\
\hline & Cornwell $^{33 *}$ & 2009-2014* & $37 *$ & $37^{*}$ & * & * & * & ?* & * & ○* \\
\hline \multirow[t]{2}{*}{ Indiana University } & Varlotto $^{34}$ & 1999-2008 & 137 & $\begin{array}{l}132^{\mathrm{L}} \\
48^{\mathrm{S}}\end{array}$ & & & ○ & $\bullet$ & & 0 \\
\hline & Varlotto $^{34 *}$ & $1999-2008^{*}$ & $77^{*}$ & $77 *$ & $*$ & * & ? & * & * & * \\
\hline William Beaumont Hospital & Grills $^{35}$ & 2003-2009 & 55 & 69 & - & ○ & 0 & & $\bullet$ & 0 \\
\hline
\end{tabular}


TABLE 1. Continued

\begin{tabular}{|c|c|c|c|c|c|c|c|c|c|c|}
\hline \multirow[b]{2}{*}{ Institution } & \multirow[b]{2}{*}{ Author } & \multirow[b]{2}{*}{ Study period } & \multicolumn{2}{|c|}{$N$} & \multirow[b]{2}{*}{ Mortality } & \multirow[b]{2}{*}{ Morbidity } & \multirow[b]{2}{*}{ OS } & \multirow[b]{2}{*}{ DFS } & \multirow[b]{2}{*}{ CSS } & \multirow[b]{2}{*}{ REC } \\
\hline & & & $\overline{\text { SBRT }}$ & $\overline{\text { Surgery }}$ & & & & & & \\
\hline \multicolumn{11}{|l|}{ Netherlands } \\
\hline \multirow[t]{2}{*}{ St. Antonius Hospital } & Kastelijn $^{36}$ & $2008-2011$ & 53 & 175 & ○ & & ○ & ○ & & - \\
\hline & Kastelijn ${ }^{36 *}$ & 2008-2011* & $23^{*}$ & $23^{*}$ & * & $*$ & $\bigcirc *$ & ○* & $*$ & O* \\
\hline \multirow[t]{2}{*}{ VU University Med Center } & Verstegen $^{37}$ & $2003-2007$ & 527 & 86 & & & & & & \\
\hline & Verstegen $^{37} *$ & $2003-2007 *$ & $64 *$ & $64 *$ & * & * & * & ○* & $*$ & * \\
\hline \multirow[t]{2}{*}{ VU and Erasmus University } & Mokhles $^{38}$ & $2003-2012$ & 481 & 96 & & & & & & \\
\hline & Mokhles $^{38 *}$ & $2003-2012 *$ & $73 *$ & $73 *$ & $O^{*}$ & ○* & $\bigcirc *$ & $*$ & $*$ & O* \\
\hline Erasmus University & Mokhles $^{39}$ & $2001-2011$ & 209 & 216 & & & ○ & & & - \\
\hline University of Groningen & van den Berg ${ }^{40}$ & $2007-2010$ & 197 & 143 & & & ○ & • & & - \\
\hline \multirow[t]{2}{*}{ Amsterdam Cancer Registry } & Palma $^{41}$ & $2005-2007$ & 81 & 109 & & & & & & \\
\hline & Palma $^{41 *}$ & $2005-2007 *$ & $60 *$ & $60 *$ & * & $*$ & * & $*$ & $*$ & * \\
\hline \multicolumn{11}{|l|}{ Japan } \\
\hline \multirow[t]{2}{*}{ Nagasaki University Hospital } & Miyazaki $^{42}$ & $2008-2014$ & 41 & 57 & ○ & - & ○ & & - & 0 \\
\hline & Miyazaki $^{42} *$ & 2008-2014* & $27^{*}$ & $27 *$ & $*$ & $*$ & * & $*$ & * & * \\
\hline \multirow[t]{4}{*}{ Kyoto University Hospital } & Hamaji $^{43}$ & 2003-2009 & 104 & 413 & $\bullet$ & & $\bullet$ & $\bullet$ & $\bullet$ & $\bullet$ \\
\hline & Hamaji $^{43 *}$ & $2003-2009 *$ & $41 *$ & $41^{*}$ & * & $*$ & * & * & * & * \\
\hline & Matsuo $^{44}$ & $2003-2009$ & 115 & 65 & ○ & & O & & O & \\
\hline & Matsuo $^{44} *$ & $2003-2009 *$ & $53^{*}$ & $53^{*}$ & O* & $*$ & $\bigcirc^{*}$ & * & $\bigcirc *$ & ○* \\
\hline Tenri and Kurashiki Hospitals & Nakagawa $^{45}$ & 2001-2011 & 35 & 183 & 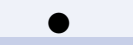 & 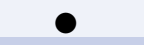 & $\bullet$ & & & 0 \\
\hline \multicolumn{11}{|l|}{ Others } \\
\hline \multirow[t]{2}{*}{ PLA General Hospital, China } & Wang $^{46}$ & $2002-2010$ & 74 & 106 & $\bullet$ & 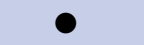 & $\bullet$ & $\bullet$ & - & $\bullet$ \\
\hline & Wang $^{46 *}$ & $2002-2010 *$ & $35^{*}$ & $35^{*}$ & $*$ & * & * & * & * & * \\
\hline Multi-institutional & Chang $^{7 *}$ & $2008-2014 *$ & $31 *$ & $27 *$ & * & * & * & * & $*$ & * \\
\hline
\end{tabular}

Dots denote presented data. Solid dots denote data selected for quantitative analysis. Asterisks indicate matching of patients by propensity score analysis or retrospective pooling of randomized data. $O S$, Overall survival; DFS, disease-free survival; $C S S$, cancer-specific survival; REC, locoregional or distant recurrence; SBRT, stereotactic body radiation therapy; SEER, Surveillance, Epidemiology, and End Results; $S$, sublobar resection; $L$, lobectomy; $N C D B$, National Cancer Database; VA, Veterans Affairs; W, wedge; VAMC, Veterans Affairs Medical Center; $V U$, Vrije Universiteit; PLA, People's Liberation Army.

\section{Propensity Score Matching}

The systematic review identified 24 studies that used propensity score matching by statistically balancing a number of covariables, which can be categorized into patient characteristics, preoperative risk factors, and tumor characteristics. The most commonly used factors included age; gender; Charlson comorbidity index; performance status; pulmonary function test; size, stage, location, and histologic profile of the tumor; and the preprocedural use of positron emission tomography. A summary of all the chosen covariates for propensity-matched studies selected for meta-analysis is presented in Table 2. When individual studies used more than 1 caliper for comparison between treatment groups, data were derived from the most detailed comparison.

\section{Patient Characteristics}

A summary of baseline characteristics of matched patients selected for meta-analysis, including age, gender, SBRT regimen, and surgical procedure details, is presented in Table 3. A summary of these details for unmatched patients is presented in Table E1. In brief, the interquartile range of ages for matched patients was 71 to 78 years for those who underwent SBRT and 68 to 78 years for those who underwent surgery. Gender variations were noted to be significantly different among studies, with 4 studies, primarily from military institutions or registries, reporting study populations comprising less than $10 \%$ female participants. ${ }^{25,26,33,46}$ SBRT regimens varied in dosage and fractions among centers and within each institution, depending on the location, size, and type of the tumor. When resection type was specified, lobectomies accounted for more than $60 \%$ of resections in the studies selected for meta-analysis, with sublobar resections accounting for the majority of the remaining surgical procedures. The use of video-assisted thoracoscopic surgery (VATS) varied among reports, with 4 studies only reporting on VATS procedures. ${ }^{16,33,37,43}$ A summary of histopathologic details and clinical staging for the matched SBRT and surgical patients is presented in Table 4. A summary of these details for unmatched patients is presented in Table E2. In brief, adenocarcinoma and squamous cell carcinoma were the most common types of NSCLC. Up to $70 \%$ of patients who underwent SBRT did not have a pretreatment pathologic diagnosis of NSCLC. ${ }^{36}$ 
TABLE 2. Summary of covariates used for propensity score matching in comparative studies on stereotactic body radiation therapy versus surgical resection for early-stage non-small cell lung cancer

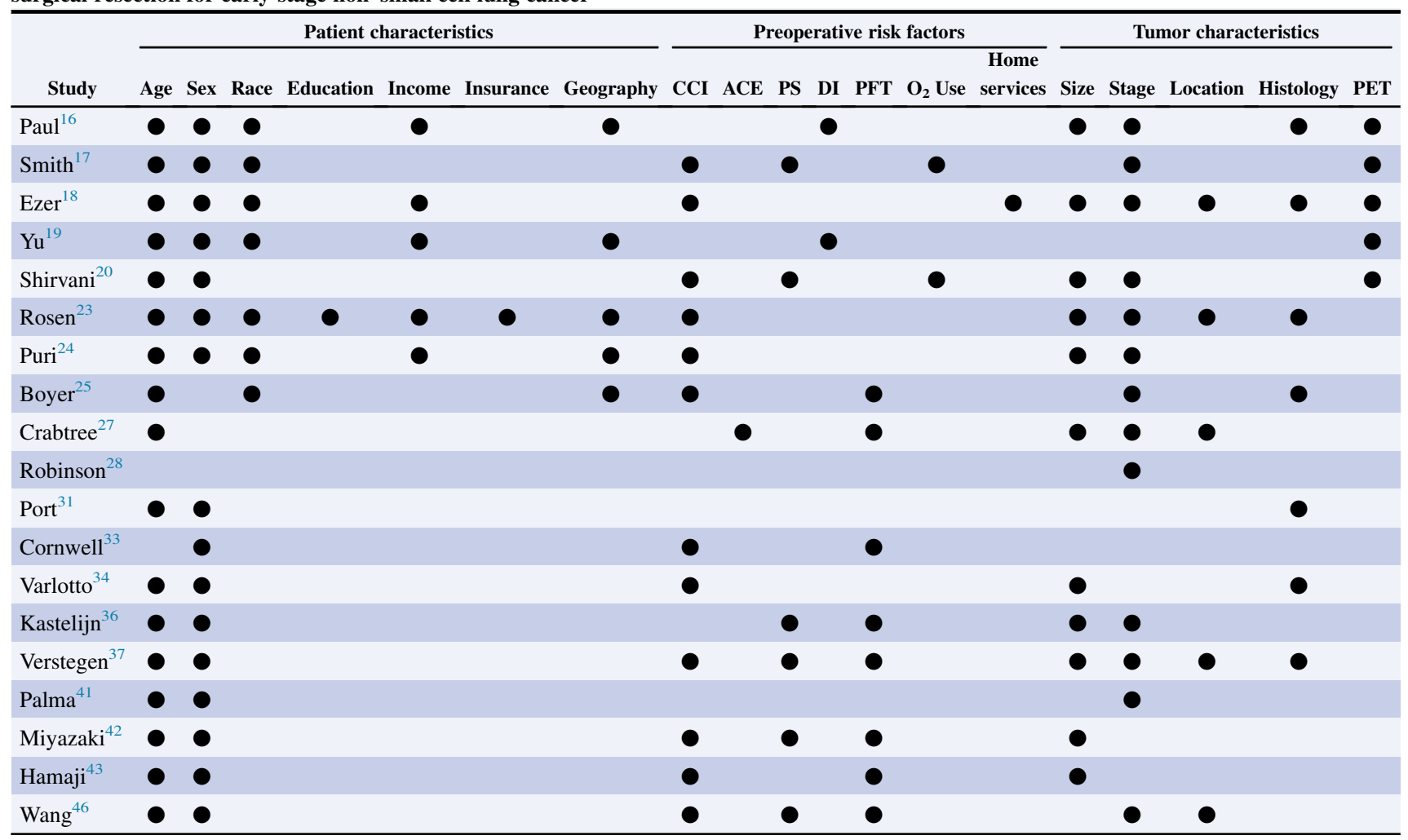

$C C I$, Charlson comorbidity index; $A C E$, adult comorbidity evaluation; $P S$, performance status; $D I$, disability index; $P F T$, pulmonary function tests; $P E T$, pretreatment position emission.

However, the proportion of patients who underwent SBRT without histopathologic confirmation appeared to differ between European centers and institutions in the United States. Histopathologic demonstration of malignancy was confirmed in more than $90 \%$ of surgical patients in all selected studies. In regard to clinical staging, $71 \%$ to $84 \%$ of matched patients who underwent SBRT had stage IA disease, and $16 \%$ to $29 \%$ had stage IB disease. For matched patients who underwent surgery, $70 \%$ to $82 \%$ had stage IA disease, and $18 \%$ to $34 \%$ had stage IB disease (staged according to the 7th edition of the TNM classification for NSCLC). ${ }^{47}$

\section{Overall Survival}

Sixteen studies provided comparative overall survival outcomes on 10,333 patients who underwent SBRT and 142,293 unmatched patients who underwent surgical resection. Fourteen studies reported overall survival for 8946 patients who underwent SBRT and 8942 matched patients who underwent surgery. The unmatched studies demonstrated a significantly superior survival outcome after surgery, compared with SBRT (OR, 2.49; 95\% confidence interval [CI], 2.10-2.94; $P<.00001$; $\mathrm{I}^{2}=86 \%$; Figure $\left.1, A\right)$. When the matched cohorts were compared, overall survival remained superior for surgery compared with SBRT (OR, 1.71; 95\% CI, 1.52-1.93; $P<.00001 ; \mathrm{I}^{2}=63 \%$; Figure $\left.1, B\right)$. Six studies in which resection type was specified reported unmatched patients who underwent SBRT or lobectomy, demonstrating superior survival outcomes after lobectomy (OR, 2.68; 95\% CI, 2.04-3.53; $P<.00001 ; \mathrm{I}^{2}=84 \%$; Figure E2). The superiority of lobectomy for overall survival persisted when matched patients from 8 studies were compared (OR, 1.61; 95\% CI, 1.23-2.12; $P=.0006 ; \mathrm{I}^{2}=77 \%$; Figure E3). Six studies compared unmatched patients who underwent SBRT or sublobar resection and found superior outcomes after sublobar resection (OR, 1.54; 95\% CI, $1.36-1.75 ; P<.00001 ; \mathrm{I}^{2}=32 \%$; Figure E4). There was an insufficient number of studies comparing matched patients who underwent SBRT or sublobar resection to conduct a meta-analysis. A reconstructed Kaplan-Meier graph of overall survival, using aggregated data on matched patients who underwent SBRT versus surgery, is shown in Figure 2.

\section{Cancer-Specific Survival}

Eight studies provided comparative data on cancerspecific survival for unmatched patients who underwent SBRT or surgery, demonstrating significantly superior outcomes after surgery (OR, 2.44; 95\% CI, 1.86-3.19; 
TABLE 3. Summary of baseline patient characteristics and treatment details of matched patients who underwent stereotactic body radiation therapy or surgical resection for early-stage non-small cell lung cancer in studies selected for meta-analysis

\begin{tabular}{|c|c|c|c|c|c|c|c|c|c|c|c|c|}
\hline \multirow[b]{4}{*}{ Authors } & \multicolumn{2}{|c|}{ Median age } & \multicolumn{2}{|c|}{ Female $(\%)$} & \multicolumn{8}{|c|}{ Treatment regimen } \\
\hline & \multirow[b]{3}{*}{ SBRT } & \multirow[b]{3}{*}{$\mathbf{S x}$} & \multirow[b]{3}{*}{ SBRT } & \multirow[b]{3}{*}{$\mathbf{S x}$} & \multicolumn{2}{|c|}{ SBRT } & \multicolumn{4}{|c|}{ Resection type (\%) } & \multicolumn{2}{|c|}{ Technique $(\%)$} \\
\hline & & & & & \multirow[b]{2}{*}{ Total Gys } & \multirow[b]{2}{*}{ Fractions } & \multirow[b]{2}{*}{ Lobectomy } & \multicolumn{2}{|r|}{ Sublobar } & \multirow[b]{2}{*}{ Other } & \multirow[b]{2}{*}{ VATS } & \multirow[b]{2}{*}{ Open } \\
\hline & & & & & & & & $\overline{\text { Wedge }}$ & Segmentectomy & & & \\
\hline Paul $^{16}$ & $78^{\mathrm{M}}$ & $78^{\mathrm{M}}$ & 60 & 62 & NR & NR & NR & NR & NR & 0 & 100 & 0 \\
\hline \multirow[t]{2}{*}{ Smith $^{17}$} & $77^{\mathrm{L}}$ & $77^{\mathrm{L}}$ & $59^{\mathrm{L}}$ & $62^{\mathrm{L}}$ & NR & NR & 100 & & 100 & 0 & $27^{\mathrm{L}}$ & $73^{\mathrm{L}}$ \\
\hline & $78^{S}$ & $78^{S}$ & $58^{\mathrm{S}}$ & $61^{\mathrm{S}}$ & & & & & & & $40^{\mathrm{S}}$ & $60^{\mathrm{S}}$ \\
\hline Shirvani $^{20}$ & NS & NS & NS & NS & NR & NR & 100 & NR & NR & NR & NR & NR \\
\hline $\operatorname{Rosen}^{23}$ & $76^{\mathrm{M}}$ & $75^{\mathrm{M}}$ & 57 & 56 & NR & $3-5$ & 100 & 0 & 0 & 0 & NR & NR \\
\hline Puri $^{24}$ & NS & NS & NS & NS & NR & NR & NS & NS & NS & NS & NR & NR \\
\hline Boyer $^{25}$ & NR & NR & NR & NR & NR & NR & NR & NR & NR & NR & NR & NR \\
\hline Crabtree $^{27}$ & $71^{\mathrm{M}}$ & $70^{\mathrm{M}}$ & 48 & 44 & $45-60$ & $3-6$ & 78 & 9 & 11 & $2^{\mathrm{B}}$ & NR & NR \\
\hline Robinson $^{28}$ & 76 & 65 & 45 & 51 & $45-54$ & $3-5$ & 94 & 0 & 0 & $3^{\mathrm{B}} 3^{\mathrm{P}}$ & NR & NR \\
\hline Cornwell $^{33}$ & 66 & 68 & 3 & 3 & $50-56$ & $4-5$ & 100 & 0 & 0 & 0 & 100 & 0 \\
\hline Varlotto 34 & NR & NR & NR & NR & $48-60$ & $3-5$ & NR & NR & NR & NR & NR & NR \\
\hline Kastelijn $^{36}$ & NR & NR & NR & NR & NR & NR & NR & NR & NR & NR & NR & NR \\
\hline Verstegen $^{37}$ & $71^{\mathrm{M}}$ & $68^{\mathrm{M}}$ & 42 & 44 & $54-60$ & $3-12$ & 100 & 0 & 0 & 0 & 100 & 0 \\
\hline Palma $^{41}$ & 79 & 79 & 33 & 33 & $32-60$ & $2-8$ & 82 & & 15 & $3^{P}$ & NR & NR \\
\hline Miyazaki ${ }^{42}$ & 82 & 82 & 33 & 27 & NR & NR & NR & NR & NR & NR & NR & NR \\
\hline Hamaji ${ }^{43}$ & 73 & 74 & 24 & 22 & $48-60$ & $4-8$ & 100 & 0 & 0 & 0 & 100 & 0 \\
\hline Wang ${ }^{46}$ & $77^{\mathrm{M}}$ & $75^{\mathrm{M}}$ & 6 & 6 & NR & NR & NR & NR & NR & NR & NR & NR \\
\hline Chang $^{7}$ & 67 & 67 & 55 & 59 & $\begin{array}{l}50-54^{\text {STARS }} \\
54-60^{\text {ROSEL }}\end{array}$ & $\begin{array}{l}3-4^{\text {STARS }} \\
4-5^{\text {ROSEL }}\end{array}$ & 88 & 4 & 0 & $8^{*}$ & 23 & 77 \\
\hline
\end{tabular}

$S B R T$, Stereotactic body radiation therapy; $S x$, surgery; VATS, video-assisted thoracoscopic surgery; $M$, mean value; $N R$, not reported; $L$, lobectomy; $S$, sublobar; $B$, bilobectomy; $P$, pneumonectomy. *VATS biopsy and abortion, $4 \%$ each.

$P<.00001 ; \mathrm{I}^{2}=58 \%$; Figure E5). Eight studies also presented cancer-specific survival data on matched patients, showing superior outcomes after surgery (OR, 1.78; 95\% CI, 1.28-2.48; $P=.0006 ; \mathrm{I}^{2}=51 \%$; Figure $1, C$ ). A reconstructed Kaplan-Meier graph of cancer-specific survival, using aggregated data on matched patients who underwent SBRT versus surgery, is shown in Figure 3.

\section{Disease-Free Survival}

Five studies provided comparative data on disease-free survival for unmatched patients who underwent SBRT or surgery, demonstrating significantly superior outcomes after surgery (OR, 2.13; 95\% CI, 1.65-2.75; $P<.00001$; $\mathrm{I}^{2}=0 \%$; Figure E6). When the analysis was limited to matched patients, 7 studies demonstrated superior disease-free survival in the surgical cohort (OR, 1.83; 95\% CI, 1.06-3.16; $P=.03 ; \mathrm{I}^{2}=82 \%$; Figure E7).

\section{Freedom From Disease Recurrence}

Six studies provided comparative data on locoregional recurrence for unmatched patients who underwent SBRT or surgery, demonstrating significantly superior outcomes after surgery (OR, 5.44; 95\% CI, 1.68-17.56; $P<.005$;
$\mathrm{I}^{2}=87 \%$; Figure E8). When the analysis was limited to matched patients, 6 studies demonstrated superior locoregional recurrence rates in the surgical cohort (OR, 2.91; 95\% CI, 1.49-5.71; $P=.002 ; \mathrm{I}^{2}=0 \%$; Figure E9).

Five studies reported distant recurrence for unmatched patients, showing a nonsignificant trend favoring surgery over SBRT (OR, $1.50 ; 95 \%$ CI, 0.96-2.34; $P=.07$; $\mathrm{I}^{2}=60 \%$ ). There was an insufficient number of studies comparing matched patients who underwent SBRT versus surgery to conduct a meta-analysis.

\section{Periprocedural Morbidity and Mortality}

Periprocedural mortality was defined as death within the same admission or within 30 days of SBRT or surgery. For matched patients, the reported periprocedural mortality was $0 \%$ for SBRT and $0 \%$ to $8 \%$ (interquartile range, $0 \%-3.25 \%$ ) for surgery. Periprocedural morbidities varied in nature and frequency after the 2 treatment modalities. The most commonly reported morbidities after SBRT were fatigue, radiation pneumonitis, chest pain, and rib fractures. The most commonly reported morbidities after surgery were prolonged air leak, pneumonia, pulmonary embolism, cardiac 
TABLE 4. Summary of histopathologic and clinical staging details of matched patients who underwent stereotactic body radiation therapy or surgical resection for early-stage non-small cell lung cancer in studies selected for meta-analysis

\begin{tabular}{|c|c|c|c|c|c|c|c|c|c|c|c|c|c|c|c|c|}
\hline \multirow[b]{2}{*}{ Author } & \multicolumn{4}{|c|}{ Histopathology - SBRT (\%) } & \multicolumn{4}{|c|}{ Histopathology - surgery (\%) } & \multicolumn{4}{|c|}{ Clinical stage - SBRT (\%) } & \multicolumn{4}{|c|}{ Clinical stage - surgery $(\%)$} \\
\hline & $\mathbf{A}$ & $\mathbf{S}$ & $\mathbf{O}$ & $\mathbf{U}$ & $\mathbf{A}$ & $\mathbf{S}$ & $\mathbf{O}$ & $\mathbf{U}$ & IA & IB & IIA & IIB/IIIA & IA & IB & IIA & IIB/IIIA \\
\hline Paul $^{16}$ & 49 & 43 & 8 & 0 & 47 & 43 & 10 & 0 & 70 & $\mathrm{NR}$ & $\mathrm{NR}$ & NR & 70 & NR & NR & NR \\
\hline Smith $^{17}$ & NR & NR & NR & NR & NR & NR & NR & NR & 82 & 18 & 0 & 0 & 82 & 18 & 0 & 0 \\
\hline Shirvani $^{20}$ & NR & NR & NR & NR & NR & NR & NR & NR & NR & NR & NR & NR & NR & NR & NR & NR \\
\hline $\operatorname{Rosen}^{23}$ & 48 & 33 & 19 & 0 & 50 & 36 & 14 & 0 & 77 & 23 & 0 & 0 & 77 & 23 & 0 & 0 \\
\hline Puri $^{24}$ & NR & NR & NR & NR & NR & NR & NR & NR & 76 & 24 & 0 & 0 & 72 & 28 & 0 & 0 \\
\hline Boyer $^{25}$ & NR & NR & NR & NR & NR & NR & NR & NR & NR & NR & NR & NR & NR & NR & NR & NR \\
\hline Crabtree $^{27}$ & NR & NR & NR & NR & NR & NR & NR & NR & NR & 29 & NR & NR & NR & 43 & NR & NR \\
\hline Robinson $^{28}$ & 45 & 33 & 21 & 1 & 60 & 33 & 3 & 4 & 74 & 22 & 4 & 0 & 77 & 20 & 3 & 0 \\
\hline Cornwell $^{33}$ & 46 & 41 & 13 & 0 & 41 & 43 & 16 & 0 & 76 & 24 & 0 & 0 & 81 & 19 & 0 & 0 \\
\hline Varlotto $^{34}$ & NR & NR & NR & NR & NR & NR & NR & NR & 100 & 0 & 0 & 0 & 100 & 0 & 0 & 0 \\
\hline Kastelijn $^{36}$ & NR & NR & NR & NR & NR & NR & NR & NR & NR & NR & NR & NR & NR & NR & NR & NR \\
\hline Verstegen $^{37}$ & 23 & 14 & 16 & 47 & 30 & 11 & 9 & 50 & 61 & 39 & 0 & 0 & 61 & 38 & 0 & 1 \\
\hline Palma $^{41}$ & NR & NR & NR & NR & NR & NR & NR & NR & 65 & 35 & 0 & 0 & 65 & 35 & 0 & 0 \\
\hline Miyazaki $^{42}$ & NR & NR & NR & NR & NR & NR & NR & NR & NR & NR & NR & NR & NR & NR & NR & NR \\
\hline Hamaji $^{43}$ & 54 & 24 & 22 & 0 & 56 & 27 & 17 & 0 & 71 & 29 & 0 & 0 & 66 & 34 & 0 & 0 \\
\hline Wang ${ }^{46}$ & 48 & 46 & 0 & 6 & 51 & 43 & 6 & 0 & 100 & 0 & 0 & 0 & 100 & 0 & 0 & 0 \\
\hline Chang $^{7}$ & 52 & 16 & 6 & 26 & 48 & 26 & 4 & 22 & 87 & 13 & 0 & 0 & 96 & 4 & 0 & 0 \\
\hline
\end{tabular}

$S B R T$, Stereotactic body radiation therapy; $A$, adenocarcinoma; $S$, squamous cell carcinoma; $O$, other type of non-small cell lung cancer; $U$, undefined; $N R$, not reported.

arrhythmia, and myocardial infarction. Summaries of the reported periprocedural mortality and morbidity outcomes for matched and unmatched patients are presented in Tables E3 and E4, respectively.

\section{DISCUSSION}

Encouraging outcomes of SBRT compared with conventional radiotherapy has led to a paradigm shift in the management of patients with early-stage NSCLC who are considered inoperable surgical candidates. $3,48,49$ Although there is currently no class I evidence to compare SBRT with surgical resection, recent guidelines from the American Society of Radiation Oncology, endorsed by the American Society of Clinical Oncology, recommend that SBRT should be considered for all patients with stage I NSCLC who are considered high risk for surgery. ${ }^{50,51}$ With the increasing prevalence of lung cancer screening programs and an aging population with increased comorbidities, there is a growing number of high-risk patients diagnosed with resectable NSCLC. ${ }^{52}$ There is an urgent need to clearly delineate the periprocedural and longterm clinical outcomes of these 2 modalities to help refine the treatment selection process for this group of patients.

The present systematic review identified 32 comparative studies with overall survival outcomes for SBRT versus surgical resection, and patients from the most updated and complete studies were divided into unmatched and matched cohorts for meta-analysis. Key findings included statistically superior outcomes for surgery for overall survival, cancer-specific survival, disease-free survival, and freedom from locoregional disease recurrence in both unmatched and matched cohorts. There was a trend favoring surgery for freedom from distant disease recurrence, but this finding was not statistically significant. After matching was performed, ORs were reduced relative to the unmatched comparisons but remained in favor of surgery. This reduction in the magnitude of benefits after matching suggests that some of the long-term clinical outcomes favoring surgery may result from an imbalance in baseline patient characteristics, preoperative comorbidities, or tumor characteristics, rather than treatment efficacy. Nonetheless, it should be noted that the present study identified the most comparable cohorts in the current literature and demonstrated that surgery remained superior to SBRT for mid- and long-term outcomes when analysis was limited to only matched patients. Subgroup analysis of lobectomy versus SBRT demonstrated superior overall survival outcomes for lobectomy for both unmatched and matched cohorts. Sublobar resection was also superior to SBRT for overall survival, although there was a limited number of studies with matched data. Reporting of perioperative mortality and morbidity outcomes varied widely across studies, with slightly higher perioperative mortality for surgery than for SBRT in both the matched and unmatched cohorts. This is consistent with recent findings of higher mortality at 


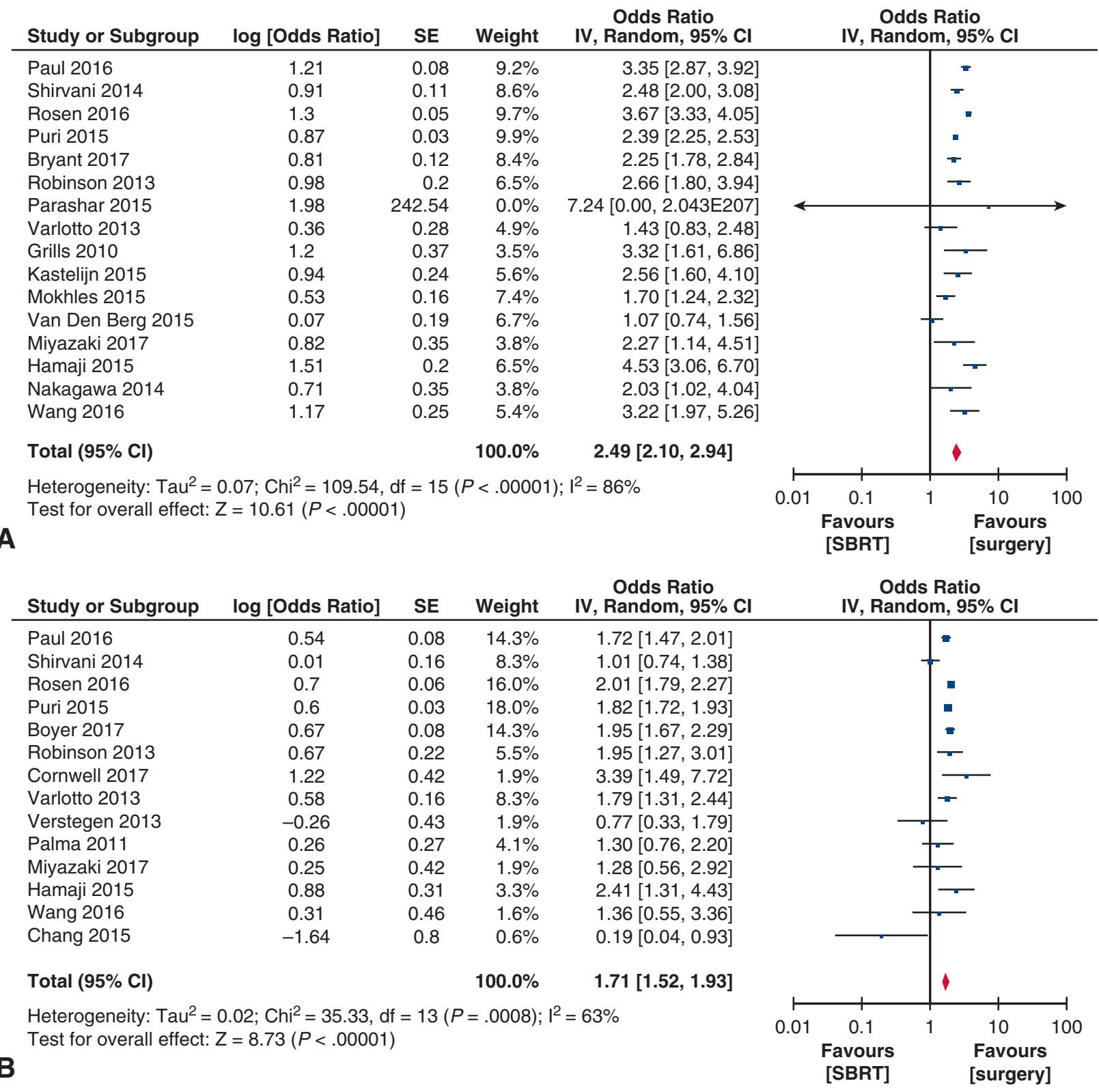

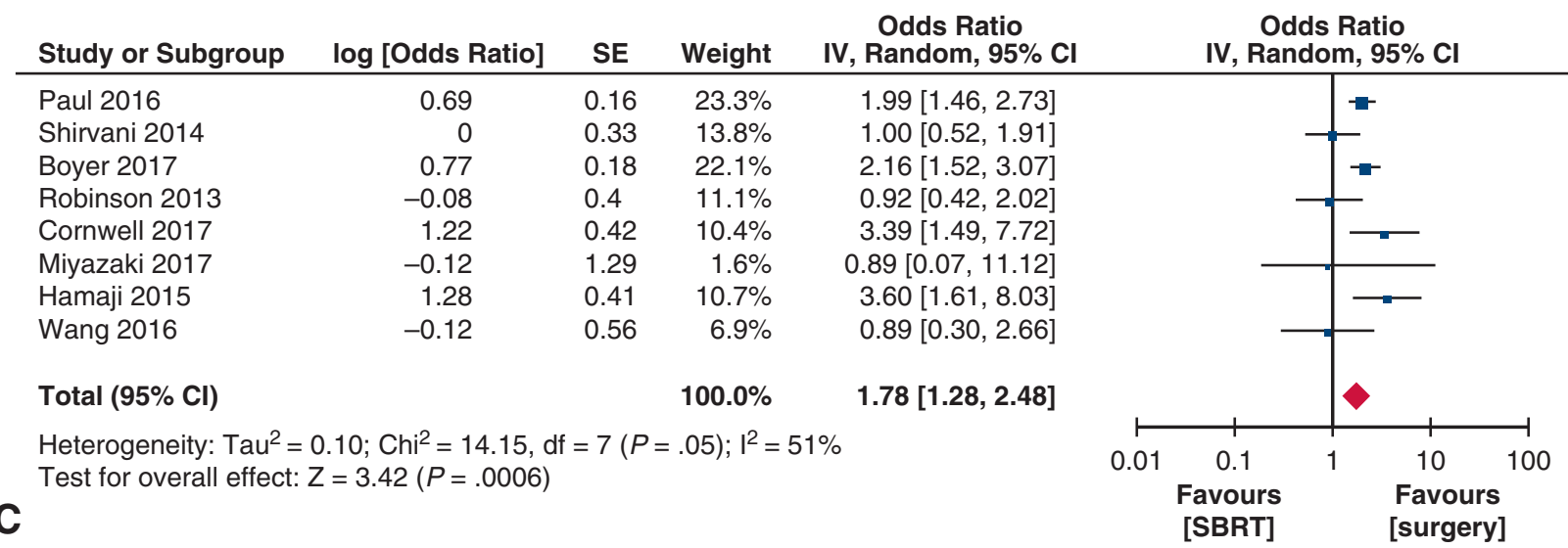

FIGURE 1. Forest plot of the OR of overall survival in unmatched patients (A), overall survival in matched patients (B), and cancer-specific survival in matched patients (C) after SBRT versus surgery in patients with early-stage NSCLC. The estimate of the OR of each study corresponds to the middle of the squares, and the horizontal line shows the $95 \%$ CI. On each line, the numbers of events as a fraction of the total number randomized are shown for both 


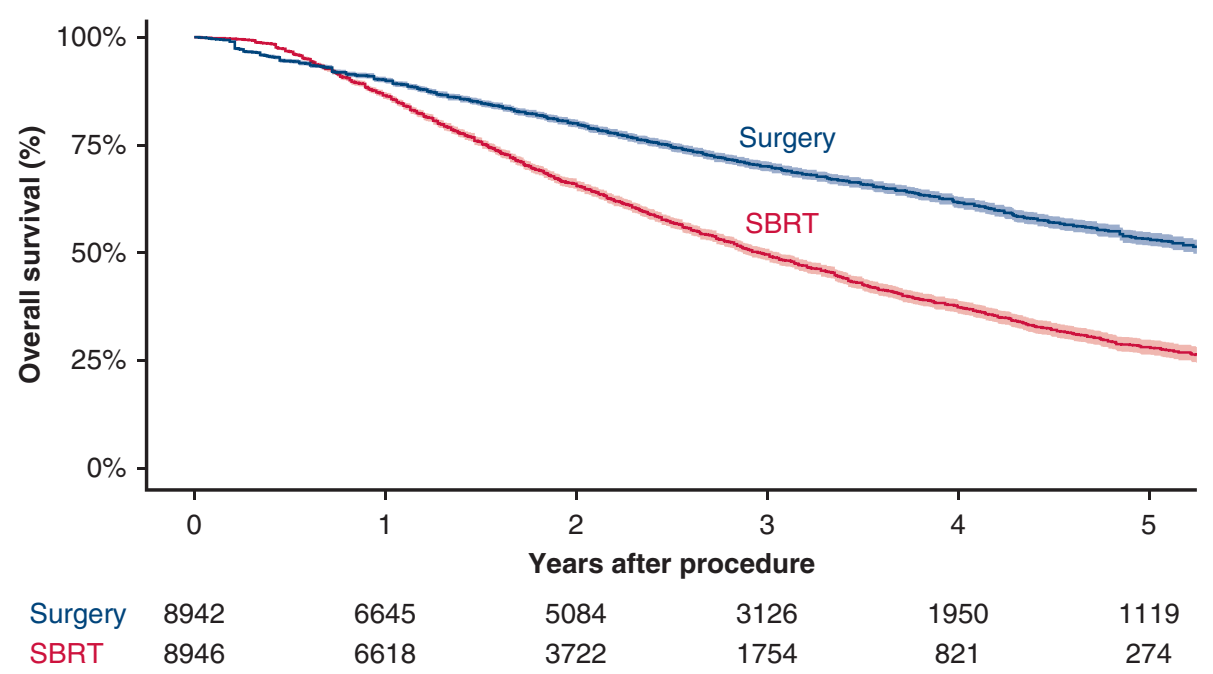

FIGURE 2. Reconstructed Kaplan-Meier graph of overall survival using aggregated data from matched patients with early-stage NSCLC who underwent SBRT versus surgery. Shading represents the $95 \%$ confidence limits around the central estimate. SBRT, Stereotactic body radiation therapy.

30 and 90 days for surgery than SBRT. ${ }^{53}$ In addition, it should be acknowledged that clinical benefits in overall and cancer-specific survival associated with surgery were not apparent until 2 to 4 years after the operation, an important consideration for patients with limited life expectancies. Other important findings from the systematic review include significant variations in patient and tumor characteristics among studies, especially between institutions in Europe and the United States. Histopathologic confirmation of NSCLC in the SBRT arm varied widely, between $30 \%$ and $100 \%$, with 5 studies reporting less than $75 \%$ of patients with a confirmed histopathologic diagnosis. ${ }^{7,36,37,39,42}$ It should be noted that 2 of these studies were the only publications that showed a trend of longer disease-free survival for SBRT than surgery. ${ }^{7,37}$

\section{Study Limitations}

The present study has several limitations. The most important limitation is the lack of level I clinical evidence in the form of randomized controlled trials and the intrinsic patient selection bias present in observational studies. Despite a strong international effort to enroll patients, only 68 of the combined target of 2410 patients $(2.8 \%)$ were ever successfully enrolled in 3 planned randomized controlled trials. ${ }^{54,55}$ Slow accrual of patients may be at least partially attributable to a lack of equipoise for surgeons who still favor surgical resections with well-established long-term clinical data ${ }^{47} \mathrm{~Pa}$ tients allocated to the SBRT arm were often those considered inoperable or high risk, with increased comorbidities that prohibited a surgical resection. The Sublobar Resection Versus Stereotactic Ablative Radiotherapy for Lung Cancer (STABLE-MATES) trial (NCT02468024 on ClinicalTrials.gov) is currently recruiting high-risk patients with peripherally located stage I NSCLC, who are randomized to SBRT or sublobar resection, with the primary end point defined as overall survival and secondary end points of progression-free survival and toxicity. In randomized trials that experienced difficulties accruing patients, one method of minimizing potential bias was to compare the 2 treatment arms using propensity scores. Although this statistical technique can balance selected observed covariates, it does not replace the robustness of randomized trials, owing to a wide range of unobserved covariates. ${ }^{10,56}$ The closeness of matching, also known as the caliper, differed among studies, depending on the reservoir of potential matches and the number of measured covariates between treatment groups. ${ }^{57}$ Additional statistical limitations of the present meta-analysis included relatively high heterogeneity identified among studies, potential overlapping of individual patients between institutions and databases, and the intrinsic limitations of the Guyot's method such as assumptions on constant censoring at each time interval. This assumption affects the relative weights of different portions of the curve, particularly as follow-up durations increase and the levels of information is reduced, potentially underestimating the uncertainty in the reconstructed hazard ratios. ${ }^{15}$ Other limitations of the current

treatment groups. For each subgroup, the sum of the statistics, along with the summary OR, is represented by the middle of the solid diamonds. A test of heterogeneity between the trials within a subgroup is given below the summary statistics. SE, Standard error; $C I$, confidence interval; SBRT, stereotactic body radiation therapy. 


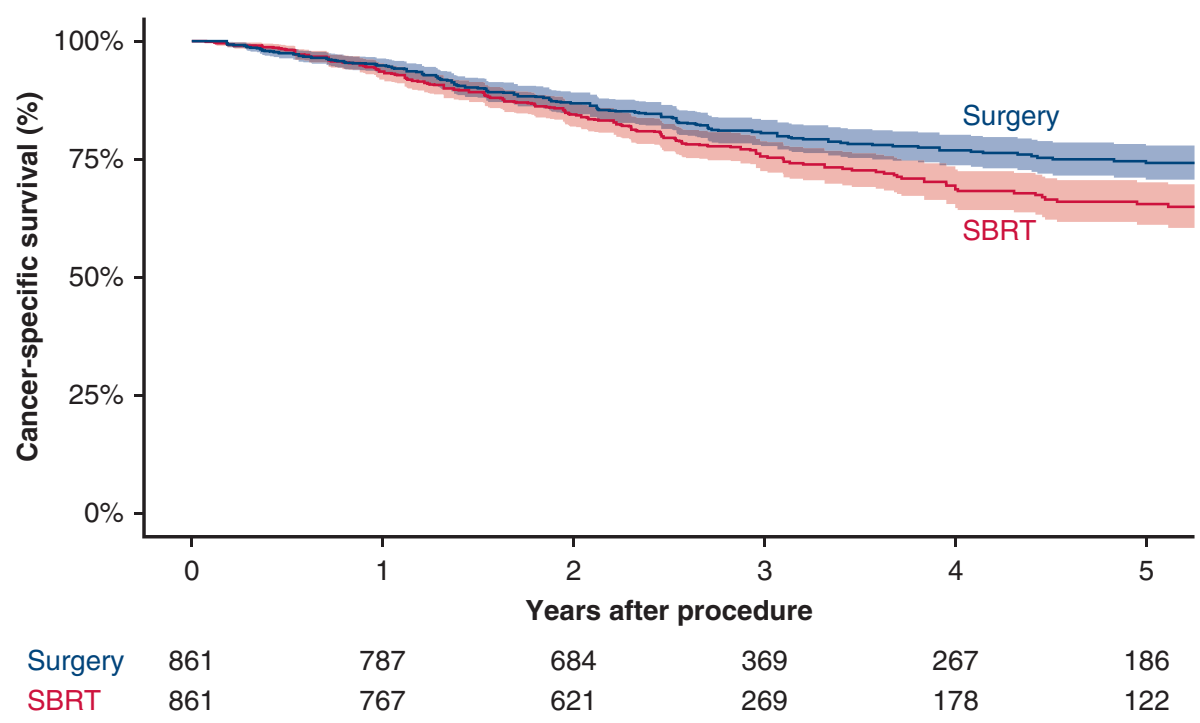

FIGURE 3. Reconstructed Kaplan-Meier graph of cancer-specific survival using aggregated data from matched patients with early-stage NSCLC who underwent SBRT versus surgery. Shading represents the $95 \%$ confidence limits around the central estimate. SBRT, Stereotactic body radiation therapy.

literature included variations in treatment regimens among institutions. Radiation dosages, doses per fraction, and treatment techniques for SBRT differed among centers, and this may have influenced the biological effective dose, treatment delivery precision, and oncologic efficacy. Surgical procedures also differed among studies, with variable portions of patients who underwent lobectomies versus sublobar resections and open thoracotomies versus VATS procedures. Future studies should compare SBRT with the current standard of care for eligible surgical candidates, which is VATS anatomic resection including lobectomy or segmentectomy, with systematic mediastinal lymph node sampling or dissection. ${ }^{58}$ Finally, it should be noted that the follow-up duration for patients who underwent SBRT was relatively short, with only 1 study with a specified imaging protocol reporting a median follow-up beyond 5 years. Unfortunately, no data for histopathologic diagnosis were provided in this study. ${ }^{40}$ Although cancer-specific survival and disease-free survival have been considered to be more appropriate end points than overall survival for comparisons of SBRT and surgery in the context of patients with significant medical comorbidities, the inconsistent reporting of histopathologic diagnosis, the variations in follow-up imaging, and the relative short-term follow-up duration make these end points difficult to interpret.

\section{CONCLUSIONS}

The present systematic review and meta-analysis of propensity-matched observational studies found surgical resection to be associated with superior overall, cancer-specific, and disease-free survival compared with SBRT. Locoregional recurrence was also found to be significantly less frequent after surgery than SBRT. However, despite propensity matching, caution should be applied when interpreting these findings, given the potential for unrecognized selection bias inherent in observational studies comparing patients with different baseline characteristics. Indeed, differences in clinical outcomes were significant, although to a smaller degree, when analyses were limited to patient cohorts matched by propensity score or retrospective pooling of randomized trials. Nonetheless, it should be recognized that the present systematic review and meta-analysis represents the best evidence in the current literature, and the key analyses performed demonstrated results that were mostly consistent in both direction and magnitude. Perioperative mortality was higher after surgery than SBRT, and the incidences and types of morbidities varied between the 2 treatment modalities. To strengthen the existing clinical evidence, future studies on SBRT should aim to confirm histopathologic diagnosis before treatment whenever possible and should provide long-term follow-up data with clearly defined imaging protocols. Surgical patients in comparative studies should undergo the current standard of care, which is VATS anatomic resection with systematic lymph node sampling or dissection. Comparing modern techniques of SBRT with the current practice of surgical resection will help refine the patient selection process and help define the optimal treatment modality for patients with earlystage NSCLC.

\section{Conflict of Interest Statement}

A.R. has received funding from Varian Medical Systems, Boehringer Ingelheim, Pfizer, and AstraZeneca. All other 
authors have nothing to disclose with regard to commercial support.

\section{References}

1. Baumann P, Nyman J, Hoyer M, Wennberg B, Gagliardi G, Lax I, et al. Outcome in a prospective phase II trial of medically inoperable stage I non-small-cell lung cancer patients treated with stereotactic body radiotherapy. J Clin Oncol. 2009; 27:3290-6.

2. Baba F, Shibamoto Y, Ogino H, Murata R, Sugie C, Iwata H, et al. Clinical outcomes of stereotactic body radiotherapy for stage I non-small cell lung cancer using different doses depending on tumor size. Radiat Oncol. 2010;5:81.

3. Jeppesen SS, Schytte T, Jensen HR, Brink C, Hansen O. Stereotactic body radiation therapy versus conventional radiation therapy in patients with early stage non-small cell lung cancer: an updated retrospective study on local failure and survival rates. Acta Oncol. 2013;52:1552-8.

4. Palma D, Visser O, Lagerwaard FJ, Belderbos J, Slotman BJ, Senan S. Impact of introducing stereotactic lung radiotherapy for elderly patients with stage I non-small-cell lung cancer: a population-based time-trend analysis. J Clin Oncol. 2010;28:5153-9.

5. Woody NM, Stephans KL, Marwaha G, Djemil T, Videtic GM. Stereotactic body radiation therapy for non-small cell lung cancer tumors greater than $5 \mathrm{~cm}$ : safety and efficacy. Int J Radiat Oncol Biol Phys. 2015;92:325-31.

6. Nagata Y, Hiraoka M, Shibata T, Onishi H, Kokubo M, Karasawa K, et al. Prospective trial of stereotactic body radiation therapy for both operable and inoperable T1N0M0 non-small cell lung cancer: Japan clinical oncology group study JCOG0403. Int J Radiat Oncol Biol Phys. 2015;93:989-96.

7. Chang JY, Senan S, Paul MA, Mehran RJ, Louie AV, Balter P, et al. Stereotactic ablative radiotherapy versus lobectomy for operable stage I non-small-cell lung cancer: a pooled analysis of two randomised trials. Lancet Oncol. 2015;16:630-7.

8. Cao C, D'Amico T, Demmy T, Dunning J, Gossot D, Hansen H, et al. Surgery versus SABR for resectable non-small-cell lung cancer. Lancet Oncol. 2015; 16:e370-1.

9. Meyers BF, Puri V, Broderick SR, Samson P, Keogan K, Crabtree TD. Lobectomy versus stereotactic body radiotherapy for stage I non-small cell lung cancer: post hoc analysis dressed up as level-1 evidence? J Thorac Cardiovasc Surg. 2015;150:468-71.

10. Rosenbaum PR, Rubin DB. The central role of propensity score in observational studies for casual effects. Biometrika. 1983;70:41-55.

11. Phan K, Tian DH, Cao C, Black D, Yan TD. Systematic review and meta-analysis: techniques and a guide for the academic surgeon. Ann Cardiothorac Surg. 2015;4:112-22.

12. Wells GS, O'Connell BD, Welch PJ, Losos V, Tugwell M. The Newcastle-Ottawa Scale (NOS) for assessing the quality of nonrandomised studies in meta-analyses. Available at: http://www.ohri.ca/programs/clinical_epidemiology/oxford.asp. Accessed October 15, 2018.

13. Tierney JF, Stewart LA, Ghersi D, Burdett S, Sydes MR. Practical methods for incorporating summary time-to-event data into meta-analysis. Trials. 2007;8:16.

14. Parmar MK, Torri V, Stewart L. Extracting summary statistics to perform meta-analyses of the published literature for survival end points. Stat Med. 1998; 17:2815-34.

15. Guyot P, Ades A, Ouwens MJ, Welton NJ. Enhanced secondary analysis of survival data: reconstructing the data from published Kaplan-Meier survival curves. BMC Med Res Methodol. 2012;12:9.

16. Paul S, Lee PC, Mao J, Isaacs AJ, Sedrakyan A. Long term survival with stereotactic ablative radiotherapy (SABR) versus thoracoscopic sublobar lung resection in elderly people: national population based study with propensity matched comparative analysis. BMJ. 2016;354:i3570.

17. Smith BD, Jiang J, Chang JY, Welsh J, Likhacheva A, Buchholz TA, et al. Cost-effectiveness of stereotactic radiation, sublobar resection, and lobectomy for early non-small cell lung cancers in older adults. J Geriatr Oncol. 2015;6: 324-31.

18. Ezer N, Veluswamy RR, Mhango G, Rosenzweig KE, Powell CA, Wisnivesky JP. Outcomes after stereotactic body radiotherapy versus limited resection in older patients with early-stage lung cancer. J Thorac Oncol. 2015;10:1201-6.

19. Yu JB, Soulos PR, Cramer LD, Decker RH, Kim AW, Gross CP. Comparative effectiveness of surgery and radiosurgery for stage I non-small cell lung cancer. Cancer. 2015;121:2341-9.

20. Shirvani SM, Jiang J, Chang JY, Welsh J, Likhacheva A, Buchholz TA, et al. Lobectomy, sublobar resection, and stereotactic ablative radiotherapy for early-stage non-small cell lung cancers in the elderly. JAMA Surg. 2014;149: 1244-53.

21. Shirvani SM, Jiang J, Chang JY, Welsh JW, Gomez DR, Swisher S, et al. Comparative effectiveness of 5 treatment strategies for early-stage non-small cell lung cancer in the elderly. Int J Radiat Oncol Biol Phys. 2012;84: 1060-70.

22. Yerokun BA, Yang CJ, Gulack BC, Li X, Mulvihill MS, Gu L, et al. A national analysis of wedge resection versus stereotactic body radiation therapy for stage IA non-small cell lung cancer. J Thorac Cardiovasc Surg. 2017; 154:675-86.e4.

23. Rosen JE, Salazar MC, Wang Z, Yu JB, Decker RH, Kim AW, et al. Lobectomy versus stereotactic body radiotherapy in healthy patients with stage I lung cancer. J Thorac Cardiovasc Surg. 2016;152:44-54.e9.

24. Puri V, Crabtree TD, Bell JM, Broderick SR, Morgensztern D, Colditz GA, et al. Treatment outcomes in stage I lung cancer: a comparison of surgery and stereotactic body radiation therapy. J Thorac Oncol. 2015;10:1776-84.

25. Boyer MJ, Williams CD, Harpole DH, Onaitis MW, Kelley MJ, Salama JK. Improved survival of stage I non-small cell lung cancer: a VA central cancer registry analysis. J Thorac Oncol. 2017;12:1814-23.

26. Bryant AK, Mundt RC, Sandhu AP, Urbanic JJ, Sharabi AB, Gupta S, et al. Stereotactic body radiation therapy versus surgery for early lung cancer among US veterans. Ann Thorac Surg. 2018;105:425-31.

27. Crabtree TD, Puri V, Robinson C, Bradley J, Broderick S, Patterson GA, et al. Analysis of first recurrence and survival in patients with stage I non-small cell lung cancer treated with surgical resection or stereotactic radiation therapy. J Thorac Cardiovasc Surg. 2014;147:1183-91; discussion 91-2.

28. Robinson CG, DeWees TA, El Naqa IM, Creach KM, Olsen JR, Crabtree TD, et al. Patterns of failure after stereotactic body radiation therapy or lobar resection for clinical stage I non-small-cell lung cancer. J Thorac Oncol. 2013; $8: 192-201$.

29. Puri V, Crabtree TD, Kymes S, Gregory M, Bell J, Bradley JD, et al. A comparison of surgical intervention and stereotactic body radiation therapy for stage I lung cancer in high-risk patients: a decision analysis. J Thorac Cardiovasc Surg. 2012;143:428-36.

30. Parashar B, Port J, Arora S, Christos P, Trichter S, Nori D, et al. Analysis of stereotactic radiation vs. wedge resection vs. wedge resection plus Cesium-131 brachytherapy in early stage lung cancer. Brachytherapy. 2015;14:648-54.

31. Port JL, Parashar B, Osakwe N, Nasar A, Lee PC, Paul S, et al. A propensity-matched analysis of wedge resection and stereotactic body radiotherapy for early stage lung cancer. Ann Thorac Surg. 2014;98:1152-9.

32. Parashar B, Patel P, Singh P, Monni S, Trichter S, Sabbas A, et al. Management of single malignant lung nodules in elderly patients (70 years or older) who are not candidates for lobectomy. Am J Clin Oncol. 2012;35:480-5.

33. Cornwell LD, Echeverria AE, Samuelian J, Mayor J, Casal RF, Bakaeen FG, et al. Video-assisted thoracoscopic lobectomy is associated with greater recurrence-free survival than stereotactic body radiotherapy for clinical stage I lung cancer. J Thorac Cardiovasc Surg. 2018;155:395-402.

34. Varlotto J, Fakiris A, Flickinger J, Medford-Davis L, Liss A, Shelkey J, et al. Matched-pair and propensity score comparisons of outcomes of patients with clinical stage I non-small cell lung cancer treated with resection or stereotactic radiosurgery. Cancer. 2013;119:2683-91.

35. Grills IS, Mangona VS, Welsh R, Chmielewski G, McInerney E, Martin S, et al. Outcomes after stereotactic lung radiotherapy or wedge resection for stage I non-small-cell lung cancer. J Clin Oncol. 2010;28:928-35.

36. Kastelijn EA, El Sharouni SY, Hofman FN, Van Putte BP, Monninkhof EM, Van Vulpen M, et al. Clinical outcomes in early-stage NSCLC treated with stereotactic body radiotherapy versus surgical resection. Anticancer Res. 2015; 35:5607-14.

37. Verstegen NE, Oosterhuis JW, Palma DA, Rodrigues G, Lagerwaard FJ, van der Elst A, et al. Stage I-II non-small-cell lung cancer treated using either stereotactic ablative radiotherapy (SABR) or lobectomy by video-assisted thoracoscopic surgery (VATS): outcomes of a propensity score-matched analysis. Ann Oncol. 2013;24:1543-8.

38. Mokhles S, Verstegen N, Maat AP, Birim O, Bogers AJ, Mokhles MM, et al. Comparison of clinical outcome of stage I non-small cell lung cancer treated surgically or with stereotactic radiotherapy: results from propensity score analysis. Lung Cancer. 2015;87:283-9.

39. Mokhles S, Nuyttens JJ, Maat AP, Birim O, Aerts JG, Bogers AJ, et al. Survival and treatment of non-small cell lung cancer stage I-II treated surgically or with stereotactic body radiotherapy: patient and tumor-specific factors affect the prognosis. Ann Surg Oncol. 2015;22:316-23. 
40. van den Berg LL, Klinkenberg TJ, Groen HJ, Widder J. Patterns of recurrence and survival after surgery or stereotactic radiotherapy for early stage NSCLC. J Thorac Oncol. 2015;10:826-31.

41. Palma D, Visser O, Lagerwaard FJ, Belderbos J, Slotman B, Senan S. Treatment of stage I NSCLC in elderly patients: a population-based matched-pair comparison of stereotactic radiotherapy versus surgery. Radiother Oncol. 2011;101:240-4.

42. Miyazaki T, Yamazaki T, Nakamura D, Sato S, Yamasaki N, Tsuchiya T, et al. Surgery or stereotactic body radiotherapy for elderly stage I lung cancer? A propensity score matching analysis. Surg Today. 2017;47:1476-83.

43. Hamaji M, Chen F, Matsuo Y, Kawaguchi A, Morita S, Ueki N, et al. Video-assisted thoracoscopic lobectomy versus stereotactic radiotherapy for stage I lung cancer. Ann Thorac Surg. 2015;99:1122-9.

44. Matsuo Y, Chen F, Hamaji M, Kawaguchi A, Ueki N, Nagata Y, et al. Comparison of long-term survival outcomes between stereotactic body radiotherapy and sublobar resection for stage I non-small-cell lung cancer in patients at high risk for lobectomy: a propensity score matching analysis. Eur J Cancer. 2014; 50:2932-8.

45. Nakagawa T, Negoro Y, Matsuoka T, Okumura N, Dodo Y. Comparison of the outcomes of stereotactic body radiotherapy and surgery in elderly patients with cT1-2N0M0 non-small cell lung cancer. Respir Investig. 2014;52:221-6.

46. Wang P, Zhang D, Guo XG, Li XM, Du LH, Sun BJ, et al. A propensity-matched analysis of surgery and stereotactic body radiotherapy for early stage non-small cell lung cancer in the elderly. Medicine (Baltimore). 2016;95:e5723.

47. Goldstraw P, Chansky K, Crowley J, Rami-Porta R, Asamura H, Eberhardt WE, et al. The IASLC lung cancer staging project: proposals for revision of the TNM stage groupings in the forthcoming (eighth) edition of the TNM classification for lung cancer. J Thorac Oncol. 2016;11:39-51.

48. Simone CB II, Wildt B, Haas AR, Pope G, Rengan R, Hahn SM. Stereotactic body radiation therapy for lung cancer. Chest. 2013;143:1784-90.

49. Timmerman R, Paulus R, Galvin J, Michalski J, Straube W, Bradley J, et al. Stereotactic body radiation therapy for inoperable early stage lung cancer. JAMA. 2010;303:1070-6.
50. Schneider BJ, Daly ME, Kennedy EB, Antonoff MB, Broderick S, Feldman J, et al. Stereotactic body radiotherapy for early-stage non-small-cell lung cancer: American Society of Clinical Oncology Endorsement of the American Society for Radiation Oncology evidence-based guideline. J Clin Oncol. 2018; 36:710-9.

51. Videtic GMM, Donington J, Giuliani M, Heinzerling J, Karas TZ, Kelsey CR, et al. Stereotactic body radiation therapy for early-stage non-small cell lung cancer: executive summary of an ASTRO evidence-based guideline. Pract Radiat Oncol. 2017;7:295-301.

52. Boffa DJ, Allen MS, Grab JD, Gaissert HA, Harpole DH, Wright CD. Data from the Society of Thoracic Surgeons general thoracic surgery database: the surgical management of primary lung tumors. J Thorac Cardiovasc Surg. 2008;135 247-54.

53. Stokes WA, Bronsert MR, Meguid RA, Blum MG, Jones BL, Koshy M, et al. Post-treatment mortality after surgery and stereotactic body radiotherapy for early-stage non-small-cell lung cancer. J Clin Oncol. 2018;36:642-51.

54. Moghanaki D, Karas T. Surgery versus SABR for NSCLC. Lancet Oncol. 2013 14:e490-1.

55. Louie AV, Senthi S, Palma DA. Surgery versus SABR for NSCLC. Lancet Oncol 2013; 14:e491.

56. Rosenbaum P, Rubin D. Reducing bias in observational studies using subclassification on the propensity score. J Am Stat Assoc. 1984;79:516-24.

57. Lunt M. Selecting an appropriate caliper can be essential for achieving good balance with propensity score matching. Am J Epidemiol. 2014;179: 226-35.

58. Yan TD, Cao C, D’Amico TA, Demmy TL, He J, Hansen H, et al. Video-assisted thoracoscopic surgery lobectomy at 20 years: a consensus statement. Eur J Cardiothorac Surg. 2014;45:633-9.

Key Words: stereotactic body radiation therapy, surgery, non-small cell lung cancer, survival, meta-analysis 


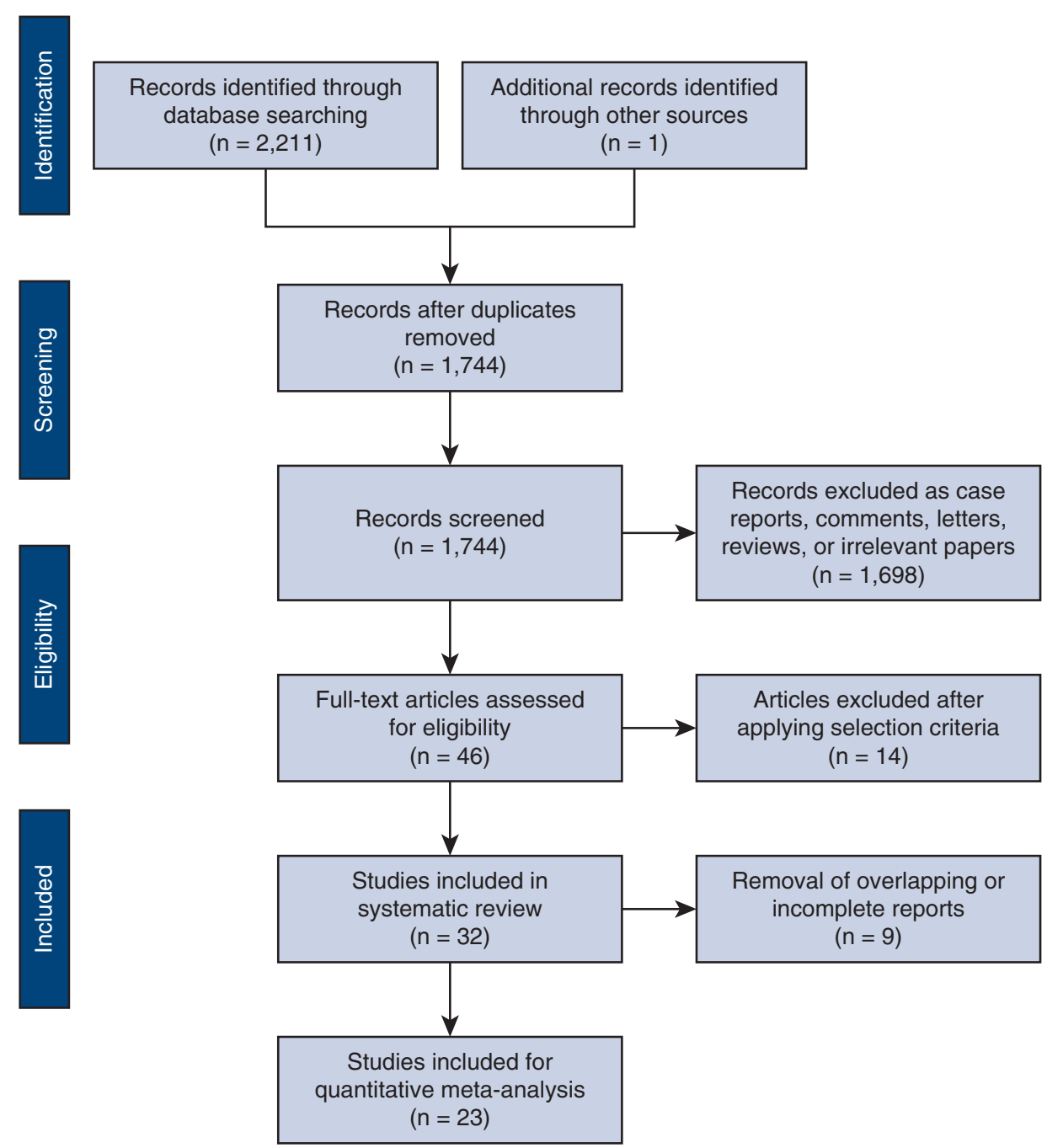

FIGURE E1. PRISMA flow chart summarizing the literature search strategy in the systematic review of SBRT versus surgical resection for patients with early-stage NSCLC.

\begin{tabular}{|c|c|c|c|c|c|c|c|c|}
\hline \multirow{2}{*}{$\begin{array}{l}\text { Study or Subgroup } \\
\text { Shirvani } 2014\end{array}$} & \multirow{2}{*}{$\frac{\text { log [Odds Ratio] }}{0.91}$} & \multirow{2}{*}{$\begin{array}{c}\text { SE } \\
0.11\end{array}$} & \multirow{2}{*}{$\begin{array}{r}\text { Weight } \\
20.0 \%\end{array}$} & \multirow{2}{*}{$\begin{array}{c}\text { Odds Ratio } \\
\text { IV, Random, 95\% CI } \\
2.48[2.00,3.08]\end{array}$} & \multicolumn{4}{|c|}{$\begin{array}{l}\text { Odds Ratio } \\
\text { IV, Random, } 95 \% \mathrm{Cl}\end{array}$} \\
\hline & & & & & & & - & \\
\hline Rosen 2016 & 1.3 & 0.05 & $22.2 \%$ & $3.67[3.33,4.05]$ & & & - & \\
\hline Bryant 2017 & 0.81 & 0.12 & $19.6 \%$ & $2.25[1.78,2.84]$ & & & 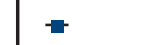 & \\
\hline Robinson 2013 & 0.98 & 0.2 & $15.6 \%$ & $2.66[1.80,3.94]$ & & & $\rightarrow-$ & \\
\hline Varlotto 2013 & 0.36 & 0.28 & $11.9 \%$ & $1.43[0.83,2.48]$ & & & - & \\
\hline Hamaji 2015 & 1.51 & 0.31 & $10.8 \%$ & $4.53[2.47,8.31]$ & & & $\longrightarrow$ & \\
\hline Total $(95 \% \mathrm{Cl})$ & & & $100.0 \%$ & $2.68[2.04,3.53]$ & & & $\gamma$ & \\
\hline \multicolumn{5}{|c|}{$\begin{array}{l}\text { Heterogeneity: } \mathrm{Tau}^{2}=0.09 ; \mathrm{Chi}^{2}=31.76, \mathrm{df}=5(P<.00001) ; \mathrm{I}^{2}=84 \% \\
\text { Test for overall effect: } Z=7.06(P<.00001)\end{array}$} & 0.0 & 0 & 10 & 100 \\
\hline
\end{tabular}

FIGURE E2. Forest plot of the OR of overall survival in unmatched patients after SBRT versus lobectomy in patients with early-stage NSCLC. The estimate of the OR of each study corresponds to the middle of the squares, and the horizontal line shows the $95 \%$ CI. On each line, the numbers of events as a fraction of the total number randomized are shown for both treatment groups. For each subgroup, the sum of the statistics, along with the summary $\mathrm{OR}$, is represented by the middle of the solid diamonds. A test of heterogeneity between the trials within a subgroup is given below the summary statistics. $S E$, Standard error; $C I$, confidence interval; SBRT, stereotactic body radiation therapy. 


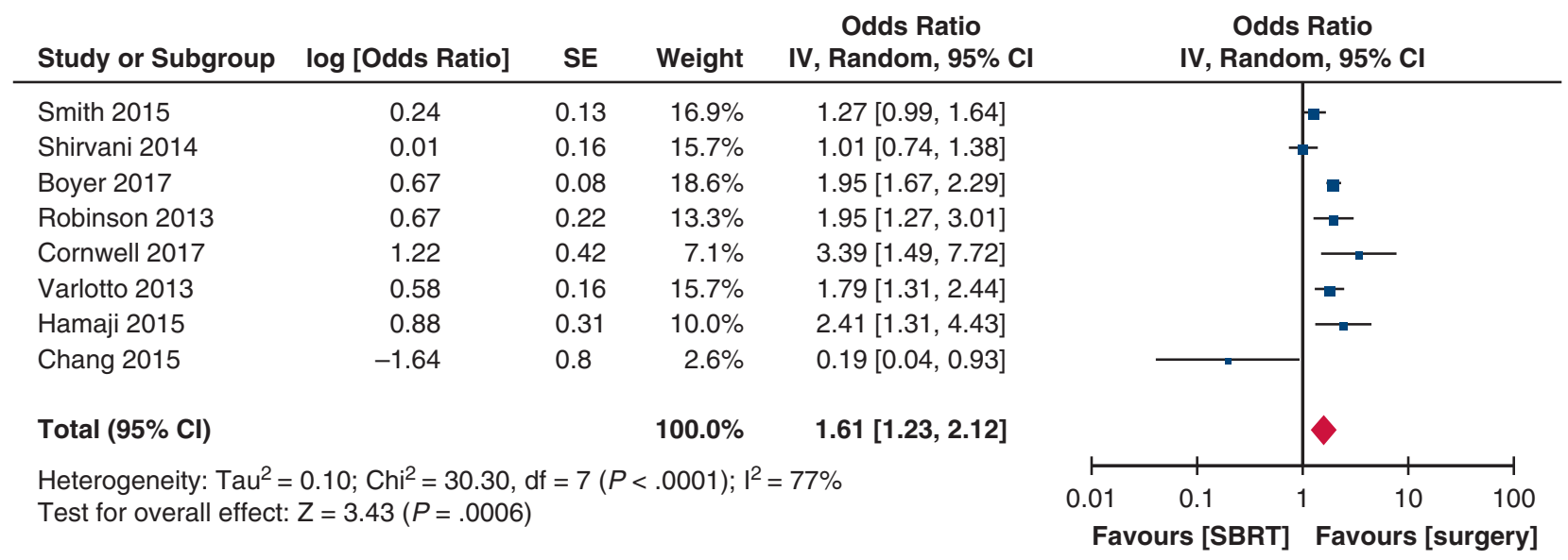

FIGURE E3. Forest plot of the OR of overall survival in matched patients after SBRT versus lobectomy in patients with early-stage NSCLC. The estimate of the OR of each study corresponds to the middle of the squares, and the horizontal line shows the $95 \% \mathrm{CI}$. On each line, the numbers of events as a fraction of the total number randomized are shown for both treatment groups. For each subgroup, the sum of the statistics, along with the summary OR, is represented by the middle of the solid diamonds. A test of heterogeneity between the trials within a subgroup is given below the summary statistics. $S E$, Standard error; $C I$, confidence interval; SBRT, stereotactic body radiation therapy.

\begin{tabular}{|c|c|c|c|c|c|c|c|c|}
\hline Study or Subgroup & log [Odds Ratio] & SE & Weight & $\begin{array}{c}\text { Odds Ratio } \\
\text { IV, Random, } 95 \% \text { CI }\end{array}$ & & IV, & $\begin{array}{l}\text { s Ratio } \\
\text { om, } 95 \% \mathrm{Cl}\end{array}$ & \\
\hline Shirvani 2014 & 0.31 & 0.1 & $23.4 \%$ & $1.36[1.12,1.66]$ & & & $=$ & \\
\hline Puri 2015 & 0.48 & 0.03 & $50.6 \%$ & $1.62[1.52,1.71]$ & & & 口 & \\
\hline Bryant 2017 & 0.37 & 0.12 & $18.6 \%$ & $1.45[1.14,1.83]$ & & & - & \\
\hline Parashar 2015 & 1.08 & 239.05 & $0.0 \%$ & $2.94[0.00,8.887 \mathrm{E} 203]$ & & & & $\rightarrow$ \\
\hline Varlotto 2013 & 0.36 & 0.28 & $4.7 \%$ & $1.43[0.83,2.48]$ & & & - & \\
\hline Grills 2010 & 1.2 & 0.37 & $2.8 \%$ & $3.32[1.61,6.86]$ & & & $\longrightarrow$ & \\
\hline Total $(95 \% \mathrm{Cl})$ & & & $100.0 \%$ & $1.54[1.36,1.75]$ & & & 1 & \\
\hline \multirow{2}{*}{\multicolumn{5}{|c|}{$\begin{array}{l}\text { Heterogeneity: } \mathrm{Tau}^{2}=0.01 ; \mathrm{Chi}^{2}=7.36, \mathrm{df}=5(P=.19) ; \mathrm{I}^{2}=32 \% \\
\text { Test for overall effect: } Z=6.89(P<.00001)\end{array}$}} & 0.01 & 0.1 & 10 & 100 \\
\hline & & & & & \multicolumn{4}{|c|}{ Favours [SBRT] Favours [surgery] } \\
\hline
\end{tabular}

FIGURE E4. Forest plot of the OR of overall survival in unmatched patients after SBRT versus sublobar resection in patients with early-stage NSCLC. The estimate of the OR of each study corresponds to the middle of the squares, and the horizontal line shows the $95 \%$ CI. On each line, the numbers of events as a fraction of the total number randomized are shown for both treatment groups. For each subgroup, the sum of the statistics, along with the summary OR, is represented by the middle of the solid diamonds. A test of heterogeneity between the trials within a subgroup is given below the summary statistics. $S E$, Standard error; $C I$, confidence interval; SBRT, stereotactic body radiation therapy. 


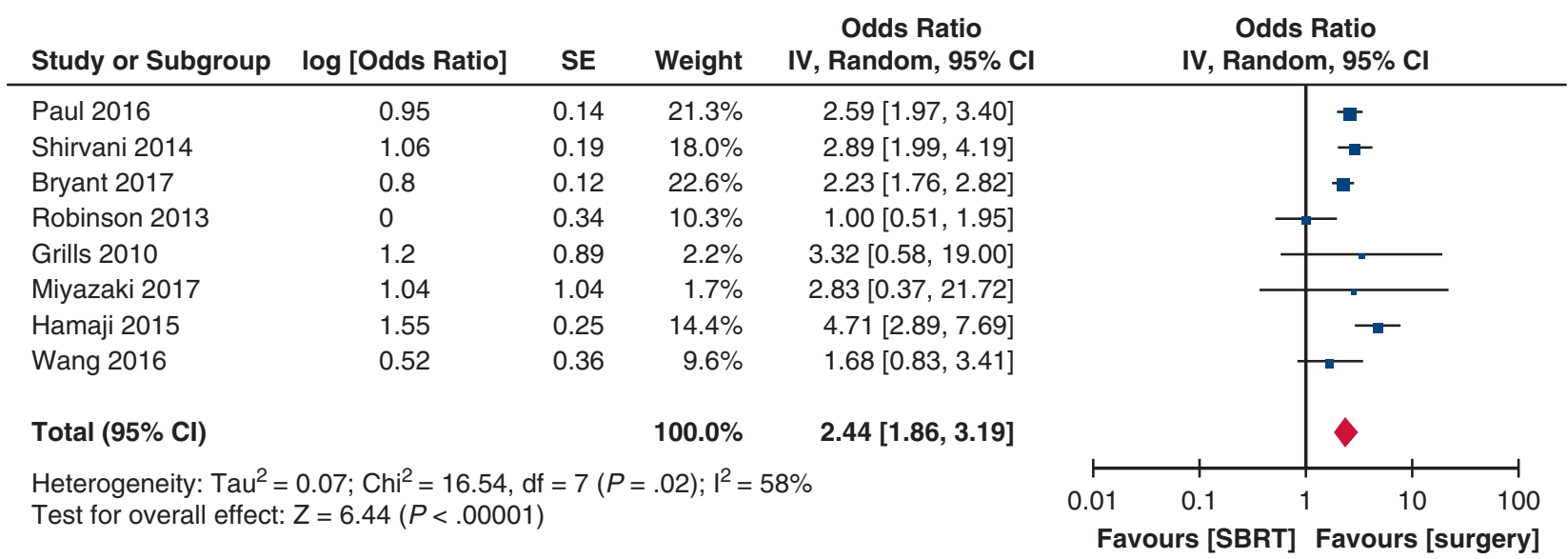

FIGURE E5. Forest plot of the OR of cancer-specific survival in unmatched patients after SBRT versus surgery in patients with early-stage NSCLC. The estimate of the OR of each study corresponds to the middle of the squares, and the horizontal line shows the $95 \%$ CI. On each line, the numbers of events as a fraction of the total number randomized are shown for both treatment groups. For each subgroup, the sum of the statistics, along with the summary OR, is represented by the middle of the solid diamonds. A test of heterogeneity between the trials within a subgroup is given below the summary statistics. $S E$, Standard error; $C I$, confidence interval; SBRT, stereotactic body radiation therapy.

\begin{tabular}{|c|c|c|c|c|c|c|c|c|c|}
\hline Study or Subgroup & log [Odds Ratio] & SE & Weight & $\begin{array}{c}\text { Odds Ratio } \\
\text { IV, Random, } 95 \% \mathrm{CI}\end{array}$ & & IV, & $\begin{array}{l}\text { Ratio } \\
\text { om, } 95^{\circ}\end{array}$ & $\% \mathrm{Cl}$ & \\
\hline Parashar 2015 & 0.79 & 0.24 & $29.2 \%$ & $2.20[1.38,3.53]$ & & & - & & \\
\hline Kastelijn 2015 & 0.83 & 0.22 & $34.8 \%$ & $2.29[1.49,3.53]$ & & & $\rightarrow-$ & & \\
\hline Van Den Berg 2015 & 0.19 & 0.59 & $4.8 \%$ & $1.21[0.38,3.84]$ & & & & & \\
\hline Hamaji 2015 & 0.9 & 0.29 & $20.0 \%$ & $2.46[1.39,4.34]$ & & & $\rightarrow$ & & \\
\hline Wang 2016 & 0.42 & 0.39 & $11.1 \%$ & $1.52[0.71,3.27]$ & & & - & & \\
\hline Total $(95 \% \mathrm{Cl})$ & & & $100.0 \%$ & $2.13[1.65,2.75]$ & & & $\diamond$ & & \\
\hline \multicolumn{5}{|c|}{$\begin{array}{l}\text { Heterogeneity: } \mathrm{Tau}^{2}=0.00 ; \mathrm{Chi}^{2}=2.04, \mathrm{df}=4(P=.73) ; \mathrm{I}^{2}=0 \% \\
\text { Test for overall effect: } \mathrm{Z}=5.82(P<.00001)\end{array}$} & 0.01 & & 1 & 10 & 100 \\
\hline
\end{tabular}

FIGURE E6. Forest plot of the OR of disease-free survival in unmatched patients after SBRT versus surgery in patients with early-stage NSCLC. The estimate of the OR of each study corresponds to the middle of the squares, and the horizontal line shows the $95 \%$ CI. On each line, the numbers of events as a fraction of the total number randomized are shown for both treatment groups. For each subgroup, the sum of the statistics, along with the summary OR, is represented by the middle of the solid diamonds. A test of heterogeneity between the trials within a subgroup is given below the summary statistics. $S E$, Standard error; $C I$, confidence interval; SBRT, stereotactic body radiation therapy.

\begin{tabular}{|c|c|c|c|c|c|c|c|c|}
\hline \multirow{2}{*}{$\begin{array}{l}\text { Study or Subgroup } \\
\text { Crabtree } 2014\end{array}$} & \multirow{2}{*}{$\frac{\text { log [Odds Ratio] }}{0.71}$} & \multirow{2}{*}{$\frac{\text { SE }}{0.29}$} & \multirow{2}{*}{$\frac{\text { Weight }}{15.5 \%}$} & \multirow{2}{*}{$\begin{array}{c}\begin{array}{c}\text { Odds Ratio } \\
\text { IV, Random, 95\% CI }\end{array} \\
2.03[1.15,3.59]\end{array}$} & \multicolumn{4}{|c|}{$\begin{array}{c}\text { Odds Ratio } \\
\text { IV, Random, } 95 \% \mathrm{CI}\end{array}$} \\
\hline & & & & & & & $\multimap-$ & \\
\hline Cornwell 2017 & 1.39 & 0.37 & $14.0 \%$ & $4.01[1.94,8.29]$ & & & 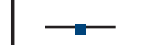 & \\
\hline Varlotto 2013 & -0.02 & 0.4 & $13.4 \%$ & $0.98[0.45,2.15]$ & & & $T$ & \\
\hline Verstegen 2013 & -0.57 & 0.38 & $13.8 \%$ & $0.57[0.27,1.19]$ & & & & \\
\hline Hamaji 2015 & 1.35 & 0.19 & $17.1 \%$ & $3.86[2.66,5.60]$ & & & $\rightarrow$ & \\
\hline Wang 2016 & 1.12 & 0.23 & $16.5 \%$ & $3.06[1.95,4.81]$ & & & $\rightarrow-$ & \\
\hline Chang 2015 & -0.35 & 0.62 & $9.7 \%$ & $0.70[0.21,2.38]$ & & & 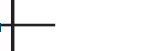 & \\
\hline Total $(95 \% \mathrm{Cl})$ & & & $100.0 \%$ & $1.83[1.06,3.16]$ & & & & \\
\hline \multicolumn{5}{|c|}{$\begin{array}{l}\text { Heterogeneity: } \mathrm{Tau}^{2}=0.42 ; \mathrm{Chi}^{2}=33.01 \text {, } \\
\text { Test for overall effect: } \mathrm{Z}=2.16(P=.03)\end{array}$} & 0.0 & 0.1 & 10 & 100 \\
\hline
\end{tabular}

FIGURE E7. Forest plot of the OR of disease-free survival in matched patients after SBRT versus surgery in patients with early-stage NSCLC. The estimate of the OR of each study corresponds to the middle of the squares, and the horizontal line shows the $95 \%$ CI. On each line, the numbers of events as a fraction of the total number randomized are shown for both treatment groups. For each subgroup, the sum of the statistics, along with the summary $\mathrm{OR}$, is represented by the middle of the solid diamonds. A test of heterogeneity between the trials within a subgroup is given below the summary statistics. $S E$, Standard error; $C I$, confidence interval; SBRT, stereotactic body radiation therapy. 


\begin{tabular}{|c|c|c|c|c|c|c|c|c|}
\hline Study or Subgroup & log [Odds Ratio] & SE & Weight & $\begin{array}{l}\text { Odds Ratio } \\
\text { IV, Random, } 95 \% \mathrm{CI}\end{array}$ & \multicolumn{4}{|c|}{$\begin{array}{l}\text { Odds Ratio } \\
\text { IV, Random, } 95 \% \mathrm{CI}\end{array}$} \\
\hline Robinson 2013 & 2.73 & 1.03 & $13.2 \%$ & $15.33[2.04,115.44]$ & & & & $\rightarrow$ \\
\hline Grills 2010 & 1.85 & 1.68 & $8.0 \%$ & $6.36[0.24,171.18]$ & & & & $>$ \\
\hline Kastelijin 2015 & 0.49 & 0.49 & $19.0 \%$ & $1.63[0.62,4.26]$ & & & - & \\
\hline Van Den Berg 2015 & 0.92 & 0.42 & $19.6 \%$ & $2.51[1.10,5.72]$ & & & $\longrightarrow$ & \\
\hline Hamaji 2015 & 3.6 & 0.4 & $19.8 \%$ & $36.60[16.71,80.16]$ & & & & $\longrightarrow$ \\
\hline Wang 2016 & 0.97 & 0.34 & $20.3 \%$ & $2.64[1.35,5.14]$ & & & 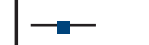 & \\
\hline Total $(95 \% \mathrm{Cl})$ & & & $100.0 \%$ & $5.44[1.68,17.56]$ & & & & \\
\hline \multirow{2}{*}{\multicolumn{5}{|c|}{$\begin{array}{l}\text { Heterogeneity: } \mathrm{Tau}^{2}=1.64 ; \mathrm{Chi}^{2}=37.41, \mathrm{df}=5(P<.00001) ; \mathrm{I}^{2}=87 \% \\
\text { Test for overall effect: } Z=2.83(P=.005)\end{array}$}} & 0.01 & 0.1 & 10 & 100 \\
\hline & & & & & \multicolumn{4}{|c|}{ Favours [SBRT] Favours [surgery] } \\
\hline
\end{tabular}

FIGURE E8. Forest plot of the OR of freedom from locoregional recurrence in unmatched patients after SBRT versus surgery in patients with early-stage NSCLC. The estimate of the OR of each study corresponds to the middle of the squares, and the horizontal line shows the $95 \%$ CI. On each line, the numbers of events as a fraction of the total number randomized are shown for both treatment groups. For each subgroup, the sum of the statistics, along with the summary OR, is represented by the middle of the solid diamonds. A test of heterogeneity between the trials within a subgroup is given below the summary statistics. SE, Standard error; $C I$, confidence interval; SBRT, stereotactic body radiation therapy.

\begin{tabular}{|c|c|c|c|c|c|c|c|c|}
\hline Study or Subgroup & log [Odds Ratio] & SE & Weight & $\begin{array}{c}\text { Odds Ratio } \\
\text { IV, Random, } 95 \% \text { CI }\end{array}$ & & IV, & $\begin{array}{l}\text { s Ratio } \\
\text { om, } 95 \% \mathrm{Cl}\end{array}$ & \\
\hline Robinson 2013 & 1.37 & 0.99 & $12.0 \%$ & $3.94[0.57,27.40]$ & & & & \\
\hline Varlotto 2013 & 2.08 & 1.99 & $3.0 \%$ & $8.00[0.16,395.57]$ & & & & $\rightarrow$ \\
\hline Verstegen 2013 & -0.63 & 0.92 & $14.0 \%$ & $0.53[0.09,3.23]$ & & & & \\
\hline Hamaji 2015 & 1.54 & 0.52 & $43.7 \%$ & $4.66[1.68,12.93]$ & & & & \\
\hline Wang 2016 & 0.85 & 0.7 & $24.1 \%$ & $2.34[0.59,9.23]$ & & & & \\
\hline Chang 2015 & 1.63 & 1.91 & $3.2 \%$ & $5.10[0.12,215.62]$ & & & & $\rightarrow$ \\
\hline Total $(95 \% \mathrm{Cl})$ & & & $100.0 \%$ & $2.91[1.49,5.71]$ & & & & \\
\hline \multicolumn{5}{|c|}{$\begin{array}{l}\text { Heterogeneity: } \mathrm{Tau}^{2}=0.00 ; \mathrm{Chi}^{2}=4.77, \mathrm{df}=5(P=.45) ; \mathrm{I}^{2}=0 \% \\
\text { Test for overall effect: } Z=3.11(P=.002)\end{array}$} & 0.01 & 0.1 & 10 & 100 \\
\hline
\end{tabular}

FIGURE E9. Forest plot of the OR of freedom from locoregional recurrence in matched patients after SBRT versus surgery in patients with early-stage NSCLC. The estimate of the OR of each study corresponds to the middle of the squares, and the horizontal line shows the $95 \%$ CI. On each line, the numbers of events as a fraction of the total number randomized are shown for both treatment groups. For each subgroup, the sum of the statistics, along with the summary OR, is represented by the middle of the solid diamonds. A test of heterogeneity between the trials within a subgroup is given below the summary statistics. SE, Standard error; $C I$, confidence interval; SBRT, stereotactic body radiation therapy. 
TABLE E1. Summary of baseline patient characteristics and treatment details of unmatched patients who underwent stereotactic body radiation therapy or surgical resection for early-stage non-small cell lung cancer in studies selected for meta-analysis

\begin{tabular}{|c|c|c|c|c|c|c|c|c|c|c|c|c|}
\hline \multirow[b]{4}{*}{ Authors } & \multicolumn{2}{|c|}{ Median age } & \multicolumn{2}{|c|}{ Female (\%) } & \multicolumn{8}{|c|}{ Treatment regimen } \\
\hline & \multirow[b]{3}{*}{ SBRT } & \multirow[b]{3}{*}{$\mathbf{S x}$} & \multirow[b]{3}{*}{ SBRT } & \multirow[b]{3}{*}{$\mathbf{S x}$} & \multicolumn{2}{|c|}{ SBRT } & \multicolumn{4}{|c|}{ Resection type (\%) } & \multicolumn{2}{|c|}{ Technique $(\%)$} \\
\hline & & & & & \multirow[b]{2}{*}{ Total Gys } & \multirow[b]{2}{*}{ Fractions } & \multirow[b]{2}{*}{ Lobectomy } & \multicolumn{2}{|r|}{ Sublobar } & \multirow[b]{2}{*}{ Other } & \multirow[b]{2}{*}{ VATS } & \multirow[b]{2}{*}{ Open } \\
\hline & & & & & & & & Wedge & Segmentectomy & & & \\
\hline Paul $^{16}$ & $79^{\mathrm{M}}$ & $79^{\mathrm{M}}$ & 61 & 61 & NR & NR & 71 & 25 & 4 & 0 & 100 & 0 \\
\hline Smith $^{17}$ & NR & NR & NR & NR & NR & NR & 83 & & 17 & 0 & NR & NR \\
\hline Shirvani $^{20}$ & NS & NS & 63 & $\begin{array}{l}53^{\mathrm{L}} \\
54^{\mathrm{S}}\end{array}$ & NR & NR & 83 & & 17 & 0 & NR & NR \\
\hline Rosen $^{23}$ & $76^{\mathrm{M}}$ & $67^{\mathrm{M}}$ & 57 & 55 & NR & $3-5$ & 100 & 0 & 0 & 0 & NR & NR \\
\hline Puri $^{24}$ & 75 & 68 & 55 & 55 & $47-61$ & NR & 74 & & 24 & $2^{\mathrm{P}}$ & NR & NR \\
\hline Boyer $^{25}$ & $72^{\mathrm{M}}$ & $67^{\mathrm{M}}$ & 1 & 3 & NR & NR & 75 & & 20 & $3^{\mathrm{P}}$ & 14 & 86 \\
\hline Bryant $^{26}$ & NR & NR & 3 & 4 & NR & NR & 82 & & 18 & 0 & NR & NR \\
\hline Crabtree $^{27}$ & $74^{\mathrm{M}}$ & $66^{\mathrm{M}}$ & 47 & 54 & $45-60$ & $3-6$ & 76 & 11 & 7 & $4^{\mathrm{P}} 2^{\mathrm{B}}$ & NR & NR \\
\hline Robinson $^{28}$ & 76 & 66 & 44 & 46 & $45-54$ & $3-5$ & 91 & 0 & 0 & $3^{\mathrm{B}} 6^{\mathrm{P}}$ & 14 & 86 \\
\hline Cornwell ${ }^{33}$ & 70 & 64 & 2 & 8 & NR & $4-5$ & 100 & 0 & 0 & 0 & 100 & 0 \\
\hline Varlotto ${ }^{34}$ & 73 & 69 & 52 & 43 & $48-60$ & $3-5$ & 73 & & 27 & 0 & NR & NR \\
\hline Grills $^{35}$ & 78 & 74 & 60 & 62 & $48-60$ & $4-5$ & 0 & 100 & 0 & 0 & 52 & 48 \\
\hline Kastelijn $^{36}$ & $72^{\mathrm{M}}$ & $67^{\mathrm{M}}$ & 64 & 38 & $54-60$ & $3-8$ & 80 & 3 & 0 & $5^{\mathrm{B}} 10^{\mathrm{P}} 2^{\mathrm{SV}}$ & 41 & 59 \\
\hline Verstegen ${ }^{37}$ & NR & NR & NR & NR & NR & NR & NR & NR & NR & NR & NR & NR \\
\hline Mokhles $^{39}$ & 74 & 65 & 35 & 34 & $45-60$ & $5-20$ & 76 & 3 & 0 & $7^{\mathrm{B}} 14^{\mathrm{P}}$ & NR & NR \\
\hline van den Berg ${ }^{40}$ & 77 & 67 & 27 & 33 & 60 & $3-12$ & 77 & 12 & 0 & $8^{\mathrm{B}} 3^{\mathrm{P}}$ & 6 & 94 \\
\hline Palma $^{41}$ & NS & NS & 29 & 29 & $32-60$ & $2-8$ & NR & NR & NR & NR & NR & NR \\
\hline Miyazaki $^{42}$ & 82 & 83 & 29 & 30 & $48-60$ & $4-10$ & 60 & 21 & 19 & 0 & NR & NR \\
\hline Hamaji $^{43}$ & 77 & 66 & 28 & 43 & $48-60$ & $4-8$ & 100 & 0 & 0 & 0 & 100 & 0 \\
\hline Nakagawa $^{45}$ & $80^{\mathrm{M}}$ & $78^{\mathrm{M}}$ & 29 & 33 & $48-60$ & $4-8$ & 84 & 2 & 13 & $1^{\mathrm{P}}$ & NR & NR \\
\hline Wang $^{46}$ & $83^{\mathrm{M}}$ & $73^{\mathrm{M}}$ & 12 & 8 & $54-60$ & $3-8$ & 60 & & 40 & 0 & 51 & 49 \\
\hline
\end{tabular}

SBRT, Stereotactic body radiation therapy; $S x$, surgery; VATS, video-assisted thoracoscopic surgery; $M$, mean value; $N R$, not reported; $L$, lobectomy; $S$, sublobar; $P$, pneumonectomy; $B$, bilobectomy; $S V$, sleeve resection. 
TABLE E2. Summary of histopathologic and clinical staging details of unmatched patients who underwent stereotactic body radiation therapy or surgical resection for early-stage non-small cell lung cancer in studies selected for meta-analysis

\begin{tabular}{|c|c|c|c|c|c|c|c|c|c|c|c|c|c|c|c|c|}
\hline \multirow[b]{2}{*}{ Author } & \multicolumn{4}{|c|}{$\begin{array}{c}\text { Histopathology - } \\
\text { SBRT }(\%)\end{array}$} & \multicolumn{4}{|c|}{$\begin{array}{c}\text { Histopathology - } \\
\text { surgery }(\%)\end{array}$} & \multicolumn{4}{|c|}{$\begin{array}{c}\text { Clinical stage - } \\
\text { SBRT (\%) }\end{array}$} & \multicolumn{4}{|c|}{$\begin{array}{c}\text { Clinical stage - } \\
\text { surgery }(\%)\end{array}$} \\
\hline & $\mathbf{A}$ & Sq & $\mathbf{O}$ & $\overline{\mathbf{U}}$ & $\overline{\mathbf{A}}$ & Sq & $\mathbf{O}$ & $\overline{\mathbf{U}}$ & $\overline{\mathbf{I A}}$ & IB & IIA & $\overline{\text { IIB/IIIA }}$ & $\overline{\mathbf{I A}}$ & IB & IIA & IIB/IIIA \\
\hline $\operatorname{Paul}^{16}$ & 49 & 43 & 8 & 0 & 49 & 27 & 24 & 0 & 70 & 30 & 0 & 0 & 67 & 33 & 0 & 0 \\
\hline Smith $^{17}$ & NR & NR & NR & NR & NR & NR & NR & NR & NR & NR & NR & NR & NR & NR & NR & NR \\
\hline Shirvani $^{20}$ & 47 & 26 & 27 & 0 & $\begin{array}{l}58^{\mathrm{S}} \\
61^{\mathrm{L}}\end{array}$ & $\begin{array}{l}32^{\mathrm{S}} \\
31^{\mathrm{L}}\end{array}$ & $\begin{array}{l}10^{\mathrm{S}} \\
8^{\mathrm{L}}\end{array}$ & 0 & 80 & 20 & 0 & 0 & $\begin{array}{l}77^{\mathrm{S}} \\
88^{\mathrm{L}}\end{array}$ & $\begin{array}{l}23^{\mathrm{S}} \\
12^{\mathrm{L}}\end{array}$ & 0 & 0 \\
\hline $\operatorname{Rosen}^{23}$ & 48 & 33 & 19 & 0 & 69 & 26 & 5 & 0 & 77 & 23 & 0 & 0 & 70 & 30 & 0 & 0 \\
\hline Puri $^{24}$ & NR & NR & NR & NR & NR & NR & NR & NR & 76 & 24 & 0 & 0 & 72 & 28 & 0 & 0 \\
\hline Boyer $^{25}$ & 24 & 42 & 26 & 9 & 50 & 38 & 10 & 2 & 51 & 49 & 0 & 0 & 55 & 45 & 0 & 0 \\
\hline Bryant $^{26}$ & 39 & 45 & 0 & 16 & $\begin{array}{l}58^{\mathrm{S}} \\
57^{\mathrm{L}}\end{array}$ & $\begin{array}{l}33^{\mathrm{S}} \\
32^{\mathrm{L}}\end{array}$ & NS & $\begin{array}{c}9^{\mathrm{S}} \\
11^{\mathrm{L}}\end{array}$ & 81 & 19 & 0 & 0 & $\begin{array}{l}88^{\mathrm{S}} \\
73^{\mathrm{L}}\end{array}$ & $\begin{array}{l}11^{\mathrm{S}} \\
27^{\mathrm{L}}\end{array}$ & 0 & 0 \\
\hline Crabtree $^{27}$ & NR & NR & NR & NR & NR & NR & NR & NR & 73 & 27 & 0 & 0 & 59 & 36 & 3 & 2 \\
\hline Robinson ${ }^{28}$ & 46 & 32 & 21 & 1 & 59 & 34 & 3 & 4 & 72 & 24 & 4 & 0 & 53 & 32 & 9 & 6 \\
\hline Cornwell ${ }^{33}$ & 43 & 41 & 16 & 0 & 65 & 26 & 9 & 0 & 75 & 25 & 0 & 0 & 74 & 26 & 0 & 0 \\
\hline Varlotto $^{34}$ & 28 & 28 & 43 & 0 & 61 & 31 & 8 & 0 & 100 & 0 & 0 & 0 & 100 & 0 & 0 & 0 \\
\hline Grills $^{35}$ & 62 & 33 & 0 & 5 & 65 & 25 & 10 & 0 & 71 & 29 & 0 & 0 & 81 & 19 & 0 & 0 \\
\hline Kastelijn $^{36}$ & 9 & 9 & 12 & 70 & 59 & 33 & 8 & 0 & 72 & 14 & 7 & 7 & 53 & 21 & 14 & 12 \\
\hline Verstegen $^{37}$ & NR & NR & NR & NR & NR & NR & NR & NR & NR & NR & NR & NR & NR & NR & NR & NR \\
\hline Mokhles $^{39}$ & 10 & 11 & 19 & 60 & 40 & 36 & 24 & 0 & 53 & 35 & 11 & 1 & 45 & 26 & 19 & 10 \\
\hline Van Den Berg ${ }^{40}$ & NR & NR & NR & NR & NR & NR & NR & NR & 64 & 36 & 0 & 0 & 58 & 42 & 0 & 0 \\
\hline Palma $^{41}$ & NR & NR & NR & NR & NR & NR & NR & NR & 90 & 10 & 0 & 0 & 39 & 61 & 0 & 0 \\
\hline Miyazaki $^{42}$ & 32 & 22 & 0 & 46 & 70 & NR & NR & NR & 80 & 20 & 0 & 0 & 72 & 28 & 0 & 0 \\
\hline Hamaji $^{43}$ & 52 & 33 & 15 & 0 & 74 & 17 & 9 & 0 & 72 & 28 & 0 & 0 & 71 & 29 & 0 & 0 \\
\hline Nakagawa $^{45}$ & 54 & 34 & 11 & 0 & 60 & 34 & 7 & 0 & 80 & 20 & 0 & 0 & 75 & 25 & 0 & 0 \\
\hline Wang $^{46}$ & 38 & 46 & 3 & 13 & 73 & 23 & 4 & 0 & 100 & 0 & 0 & 0 & 100 & 0 & 0 & 0 \\
\hline
\end{tabular}

SBRT, Stereotactic body radiation therapy; $A$, adenocarcinoma; $S q$, squamous cell carcinoma; $O$, other type of non-small cell lung cancer; $U$, undefined; $N R$, not reported; $S$, sublobar; $L$, lobectomy. 
TABLE E3. Summary of perioperative morbidity and mortality outcomes in matched patients who underwent stereotactic body radiation therapy or surgical resection for early-stage non-small cell lung cancer in studies selected for meta-analysis

\begin{tabular}{|c|c|c|c|c|c|c|c|c|c|c|c|}
\hline \multirow[b]{2}{*}{ Author } & \multicolumn{2}{|c|}{ Mortality (\%) } & \multicolumn{5}{|c|}{ Surgical morbidity $(\%)$} & \multicolumn{4}{|c|}{ SBRT morbidity ( $\%$ ) } \\
\hline & SBRT & Surgery & Air leak & Pneumonia & PE & $\begin{array}{c}\text { Cardiac } \\
\text { arrhythmia }\end{array}$ & MI & $\begin{array}{c}\text { Rib } \\
\text { fracture }\end{array}$ & Pneumonitis & $\begin{array}{c}\text { Chest } \\
\text { pain }\end{array}$ & Fatigue \\
\hline $\mathrm{Paul}^{16}$ & NR & NR & NR & NR & NR & NR & NR & NR & NR & NR & NR \\
\hline Smith $^{17}$ & NR & NR & NR & NR & NR & NR & NR & NR & NR & NR & NR \\
\hline Shirvani ${ }^{20}$ & NR & NR & NR & NR & NR & NR & NR & NR & NR & NR & NR \\
\hline $\operatorname{Rosen}^{23}$ & NR & 3 & NR & NR & NR & NR & NR & NR & NR & NR & NR \\
\hline Puri $^{24}$ & NR & 3 & NR & NR & NR & NR & NR & NR & NR & NR & NR \\
\hline Boyer $^{25}$ & NR & NR & NR & NR & NR & NR & NR & NR & NR & NR & NR \\
\hline Crabtree $^{27}$ & NR & NR & NR & NR & NR & NR & NR & NR & NR & NR & NR \\
\hline Robinson $^{28}$ & 0 & NR & NR & NR & NR & NR & NR & NR & NR & NR & NR \\
\hline Cornwell $^{33}$ & 0 & 0 & 0 & 0 & 0 & 5 & 0 & 0 & 8 & 11 & 0 \\
\hline Varlotto $^{34}$ & NR & NR & NR & NR & NR & NR & NR & NR & NR & NR & NR \\
\hline Kastelijn ${ }^{36}$ & NR & NR & NR & NR & NR & NR & NR & NR & NR & NR & NR \\
\hline Verstegen $^{37}$ & 0 & 2 & 0 & 0 & 0 & 0 & 0 & 0 & 2 & 1 & 0 \\
\hline Palma $^{41}$ & 2 & 8 & NR & NR & NR & NR & NR & NR & NR & NR & NR \\
\hline Miyazaki $^{42}$ & NR & 0 & NR & NR & NR & NR & NR & NR & NR & NR & NR \\
\hline Hamajii ${ }^{43}$ & 0 & 0 & NR & NR & NR & NR & NR & NR & NR & NR & NR \\
\hline Wang ${ }^{46}$ & NR & NR & NR & NR & NR & NR & NR & NR & NR & NR & NR \\
\hline Chang $^{7}$ & 0 & 4 & 0 & 7 & 0 & 4 & 0 & 3 & NR & NR & 3 \\
\hline
\end{tabular}

SBRT, Stereotactic body radiation therapy; $P E$, pulmonary embolism; $M I$, myocardial infarction; $N R$, not reported. 
TABLE E4. Summary of perioperative morbidity and mortality outcomes in unmatched patients who underwent stereotactic body radiation therapy or surgical resection for early-stage non-small cell lung cancer in studies selected for meta-analysis

\begin{tabular}{|c|c|c|c|c|c|c|c|c|c|c|c|}
\hline \multirow[b]{2}{*}{ Author } & \multicolumn{2}{|c|}{ Mortality (\%) } & \multicolumn{5}{|c|}{ Surgical morbidity $(\%)$} & \multicolumn{4}{|c|}{ SBRT morbidity (\%) } \\
\hline & SBRT & Surgery & $\begin{array}{l}\text { Air } \\
\text { leak }\end{array}$ & Pneumonia & $\mathbf{P E}$ & $\begin{array}{c}\text { Cardiac } \\
\text { arrhythmia }\end{array}$ & MI & $\begin{array}{c}\text { Rib } \\
\text { fracture }\end{array}$ & Pneumonitis & $\begin{array}{c}\text { Chest } \\
\text { pain }\end{array}$ & Fatigue \\
\hline $\operatorname{Paul}^{16}$ & NR & NR & NR & NR & NR & NR & NR & NR & NR & NR & NR \\
\hline Smith $^{17}$ & NR & NR & NR & NR & NR & NR & NR & NR & NR & NR & NR \\
\hline Shirvani ${ }^{20}$ & NR & NR & NR & NR & NR & NR & NR & NR & NR & NR & NR \\
\hline $\operatorname{Rosen}^{23}$ & NR & 2 & NR & NR & NR & NR & NR & NR & NR & NR & NR \\
\hline Puri $^{24}$ & NR & 2 & NR & NR & NR & NR & NR & NR & NR & NR & NR \\
\hline Boyer $^{25}$ & NR & NR & NR & 13 & NR & NR & NR & NR & 1 & NR & NR \\
\hline Bryant $^{26}$ & 1 & 2 & NR & NR & NR & NR & NR & NR & NR & NR & NR \\
\hline Crabtree $^{27}$ & 1 & 1 & NR & NR & NR & NR & NR & NR & NR & NR & NR \\
\hline Robinson $^{28}$ & 0 & 2 & 4 & 0 & 0 & 12 & 2 & NR & 8 & 0 & 0 \\
\hline Cornwell $^{33}$ & NR & NR & NR & NR & NR & NR & NR & NR & NR & NR & NR \\
\hline Varlotto $^{34}$ & NR & NR & NR & NR & NR & NR & NR & NR & NR & NR & NR \\
\hline Grills $^{35}$ & 0 & 0 & 0 & 3 & 0 & 6 & 0 & 12 & 20 & 0 & 27 \\
\hline Kastelijn $^{36}$ & 0 & 2 & NR & NR & NR & NR & NR & NR & NR & NR & NR \\
\hline Verstegen $^{37}$ & NR & NR & NR & NR & NR & NR & NR & NR & NR & NR & NR \\
\hline Mokhles $^{38}$ & NR & NR & NR & NR & NR & NR & NR & NR & NR & NR & NR \\
\hline van den Berg ${ }^{40}$ & NR & NR & NR & NR & NR & NR & NR & NR & NR & NR & NR \\
\hline Palma $^{41}$ & NR & NR & NR & NR & NR & NR & NR & NR & NR & NR & NR \\
\hline Miyazaki $^{42}$ & NR & 0 & 12 & 7 & 0 & 6 & 0 & 0 & 17 & 0 & 0 \\
\hline Hamaji $^{43}$ & 0 & 0 & NR & NR & NR & NR & NR & NR & NR & NR & NR \\
\hline Nakagawa $^{45}$ & 3 & 1 & NR & NR & NR & NR & NR & NR & NR & NR & NR \\
\hline Wang $^{46}$ & 0 & 2 & NR & NR & NR & NR & NR & NR & NR & NR & NR \\
\hline
\end{tabular}

$S B R T$, Stereotactic body radiation therapy; $P E$, pulmonary embolism; $M I$, myocardial infarction; $N R$, not reported. 